\title{
Exercise and Bone Mass in Adults
}

\author{
Amelia Guadalupe-Grau, Teresa Fuentes, Borja Guerra and Jose A.L. Calbet
}

Department of Physical Education, University of Las Palmas de Gran Canaria, Las Palmas de Gran Canaria, Canary Islands, Spain

\section{Contents}

Abstract. ....................................................... 439

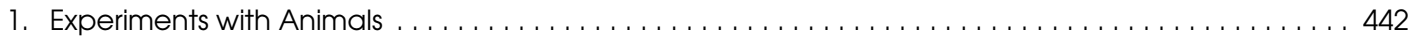

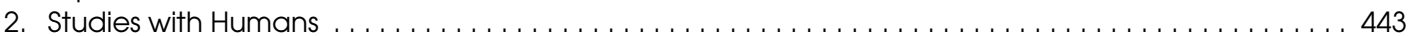

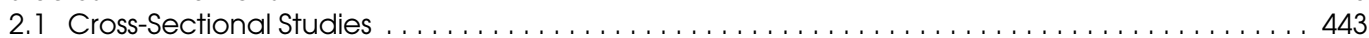

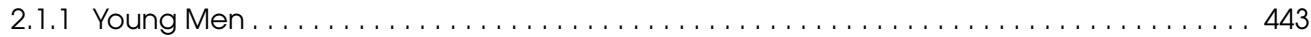

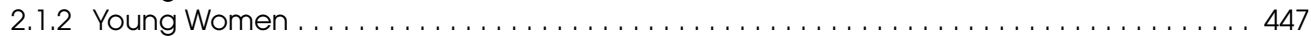

2.2 Longitudinal Studies................................................. 447

2.2.1 Young Women . . . . . . . . . . . . . . . . . . . . . . . . . . . . . . . . . . . . . . . . . . . 448

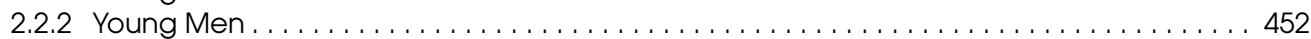

2.2.3 Premenopausal Women. . . . . . . . . . . . . . . . . . . . . . . . . . . . . . . 453

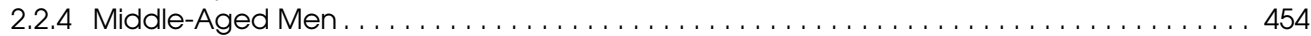

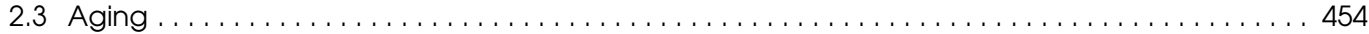

2.4 Postmenopausal Women . . . . . . . . . . . . . . . . . . . . . . . . . . . . . . . . . . . . . . . . . 455

2.5 Older Men ........................................................... 460

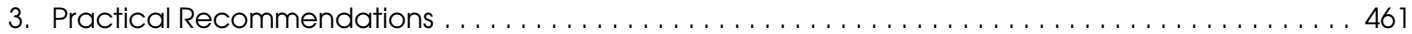

4. Conclusions.................................................... 462

\section{Abstract}

There is a substantial body of evidence indicating that exercise prior to the pubertal growth spurt stimulates bone growth and skeletal muscle hypertrophy to a greater degree than observed during growth in non-physically active children. Bone mass can be increased by some exercise programmes in adults and the elderly, and attenuate the losses in bone mass associated with aging. This review provides an overview of cross-sectional and longitudinal studies performed to date involving training and bone measurements. Crosssectional studies show in general that exercise modalities requiring high forces and/or generating high impacts have the greatest osteogenic potential. Several training methods have been used to improve bone mineral density (BMD) and content in prospective studies. Not all exercise modalities have shown positive effects on bone mass. For example, unloaded exercise such as swimming has no impact on bone mass, while walking or running has limited positive effects.

It is not clear which training method is superior for bone stimulation in adults, although scientific evidence points to a combination of high-impact (i.e. jumping) and weight-lifting exercises. Exercise involving high impacts, even a relatively small amount, appears to be the most efficient for enhancing bone mass, except in postmenopausal women. Several types of resistance exercise have been tested also with positive results, especially when the 
intensity of the exercise is high and the speed of movement elevated. A handful of other studies have reported little or no effect on bone density. However, these results may be partially attributable to the study design, intensity and duration of the exercise protocol, and the bone density measurement techniques used. Studies performed in older adults show only mild increases, maintenance or just attenuation of BMD losses in postmenopausal women, but net changes in BMD relative to control subjects who are losing bone mass are beneficial in decreasing fracture risk. Older men have been less studied than women, and although it seems that men may respond better than their female counterparts, the experimental evidence for a dimorphism based on sex in the osteogenic response to exercise in the elderly is weak. A randomized longitudinal study of the effects of exercise on bone mass in elderly men and women is still lacking. It remains to be determined if elderly females need a different exercise protocol compared with men of similar age. Impact and resistance exercise should be advocated for the prevention of osteoporosis. For those with osteoporosis, weight-bearing exercise in general, and resistance exercise in particular, as tolerated, along with exercise targeted to improve balance, mobility and posture, should be recommended to reduce the likelihood of falling and its associated morbidity and mortality. Additional randomized controlled trials are needed to determine the most efficient training loads depending on age, sex, current bone mass and training history for improvement of bone mass.

The most important function of bone tissue is to withstand and transmit forces without breaking. The strength of bone depends on the amount of tissue, its material composition and how bone material is organized microarchitecturally and geometrically (shape and size). ${ }^{[1,2]}$ As summarized by Seeman and Delmas, ${ }^{[3]}$ optimal bone tissue characteristics are defined by optimal levels of stiffness, flexibility and lightness. To efficiently withstand and transmit loads, bone must be stiff and able to resist deformation. However, it cannot be too stiff - i.e. unable to absorb some energy by shortening and widening when compressed, and by lengthening and narrowing when submitted to traction - otherwise the energy imposed during loading will be released by structural failure. Conversely, bone cannot be too flexible, because on loading it could easily deform beyond its peak strain, and fracture. ${ }^{[3]}$ Bone must also have the ability to continually adapt to changes in physiological and mechanical environment.

The mechanical properties of bone are determined by two major factors: the characteristics of the collagen matrix and the degree of mineralization, i.e. the amount of calcium hydroxyapatite crystals deposited on and between the collagen fibres. Bone strength is primarily determined by tissue mass and stiffness. While stiffness is mainly determined by the mineral phase, ${ }^{[4-7]}$ the collagen matrix contributes primarily to bone toughness resilience (i.e. the ability to absorb energy without breaking). ${ }^{[8-10]}$ Increasing bone mineral density (BMD) results in greater stiffness but lower flexibility. ${ }^{[1]}$

Collagen, of which about $95 \%$ is type I collagen, comprises about $80 \%$ of the total protein in bone. ${ }^{[12]}$ Collagen fibres are packed together by the formation of inter- and intramolecular crosslinks. Mature crosslinks such as pyridinoline (PYD) and deoxypyridinoline (DPD) reach a maximum concentration between 15 and 40 years of age, and their concentrations are lower in trabecular bone than in cortical bone. ${ }^{[13]}$ If there are too many crosslinks, the ability to absorb energy diminishes, i.e. the bone becomes more brittle. Likewise, without the collagen matrix the bone becomes less elastic and more brittle. ${ }^{[14]}$ In 
humans it has been shown that the compressive biomechanical ultimate strength of bone is correlated, independently of $\mathrm{BMD}$, with the ratio PYD/DPD, but not with PYD, DPD or pyrrole separately. ${ }^{[15]}$ Non-fibrillar organic matrix acts as the 'glue' that holds the mineralized fibrils together. ${ }^{[16]}$

Bone strength also depends on the orientation of osteons (and thus collagen fibres) within the cortical bone. ${ }^{[17]}$ Longitudinal fibres are found in regions supporting tensile loads, while transverse fibres predominate in regions under compressive loading. ${ }^{[2,18]}$ Part of the bone plasticity in response to loading depends on its capacity to reorient its collagen fibres. For example, it has been reported in dogs that a $10 \%$ reduction in vertebral BMD elicited by a strenuous progressive running programme (up to $40 \mathrm{~km} /$ day) for 1 year did not change the bone mechanical properties. ${ }^{[19]}$ These dogs, compared with their sedentary counterparts, showed reorganization of the collagen fibres in a more parallel manner without changes in the concentration of crosslinks, suggesting that collagen reorganization during exercise may contribute to the maintenance of bone strength despite decreased mineral density. ${ }^{[19]}$

Bone mechanical properties are modified depending on loading, such that bone strength is enhanced or reduced in response to either increased or reduced mechanical loading. ${ }^{[3,20-22]}$ The adaptive response is very complex and depends on the characteristics of loading history, but also on systemic and local factors, which include neuroendocrine, endocrine and paracrine changes in metabolites, cytokines, growth factors, hormones, vitamins and minerals. ${ }^{[23-27]}$ Excellent reviews have been published recently on the molecular mechanisms that mediate adaptive responses of bone tissue to changes in loading, and the interested reader is referred to them. ${ }^{[24-26,28,29]}$ The main signals for bone adaptation to mechanical loading are the rate and magnitude of strain, which should reach minimal levels or threshold to elicit structural modifications in bone. ${ }^{[30-33]}$ To enhance bone mass or BMD in non-physically active humans, bone tissue must be submitted to mechanical strains above those experienced by daily living activities. ${ }^{[31,34]}$
Although experimental evidence indicates that mechanical loads must be great to augment bone mass, to induce bone strains sufficient to cause microdamage and stimulate bone formation through the repair of damaged tissue, ${ }^{[35,36]}$ the intensity of loading is not the only stimulus for bone accretion, as demonstrated by Rubin et al. ${ }^{[37,38]}$ These authors demonstrated that high frequency vibration $(20-50 \mathrm{~Hz})$ of very low magnitude ( $<10$ microstrain), continually present during even subtle activities such as standing, increases trabecular bone mass in weight-bearing regions of the skeleton in animals. ${ }^{[37-39]}$

Mechanical loading triggers a cascade of cellular events that involve estrogen receptoralpha $(E R \alpha){ }^{[26]}$ This may be the reason why the osteogenic effect of loading is greater when the estrogen receptor number is high, as during adolescence, and less when the estrogen receptor number is low, as occurs postmenopausally, during amenorrhoea, or after ovariectomy. ${ }^{[26]}$ Signals from calcium channels, G-proteins, integrins and the cytoskeleton elicited by mechanical loading are conveyed in the activation of key intracellular enzymes leading to release of nitric oxide, prostaglandin $\mathrm{E}_{2}$, transforming growth factor $\beta$, insulin-like growth factor (IGF)-I or IGF-II, ultimately leading to bone formation. ${ }^{[28,29]}$

Osteoporosis is a reduction in BMD 2.5 standard deviations below the mean for healthy young women at the age of attainment of peak bone mass (expressed as a T-score), in general using a reference population matched for age, sex and race (expressed as a Z-score). ${ }^{[40]}$ Loss of BMD contributes to loss of mechanical strength and to bone fragility, and thus to predisposition for bone fractures, which may occur even under low loading conditions, as reviewed elsewhere. ${ }^{[40-43]}$ This condition is a considerable worldwide concern and a cause of high healthcare costs. ${ }^{[44]}$

Although some risk factors for osteoporosis, like genetics (sex, age, body size and ethnicity), cannot be modified, it is possible to change variables like lifestyle and physical activity to stimulate greater accumulation of peak bone mass. ${ }^{[45]}$ Sports participation during childhood and adolescence, ${ }^{[46-50]}$ especially before the pubertal growth spurt, ${ }^{[51-58]}$ promotes bone mass accumulation, 
i.e. gain in total bone mineral content (BMC), and geometrical changes in bone size and shape leading to a higher bone mass and stronger bones in adult life. ${ }^{[40,56,59,60]}$ In fact, epidemiological studies indicate that bone size is related to fracture risk when examined in relation to body size in children, ${ }^{[61]}$ and participation in sports prior to puberty promotes bone hypertrophy, i.e. physically active pre-pubertal children appear to develop bone of greater size than their sedentary peers, although this effect is confined to the loaded regions. ${ }^{[59,62]}$

Although well documented reviews have been published in postmenopausal women, ${ }^{[3,40,42,63]}$ less is known about the effects that exercise programmes and sports participation may have on bone mass in young adult women at premenopausal age. ${ }^{[64]}$ Thus, this article focuses on the influence of physical activity on BMC and BMD in premenopausal and postmenopausal women and in men. In addition, we review relevant studies in animals and humans, highlighting variables like mode of exercise, intensity, duration, endocrine and metabolic factors, and sex differences in the osteogenic response to training.

A MEDLINE database search was conducted (from 1969 to June 2008, with a special focus on the latest publications), using the following systematic search terms: 'bone', 'bone mineral density (BMD)', 'bone mineral content (BMC)', 'dual x-ray absorptiometry (DXA)', 'bone mass accrual', combined with 'exercise', 'sports participation', 'adults'. The abstract of studies resulting from this search were examined according to the following criteria:

Inclusion criteria:

- sports participation and bone mass measurements in adults;

- effects of training on bone mass in adults;

- effects of vibration on bone mass in adults;

- sex differences in the osteogenic response to training;

Exclusion criteria:

- prepubertal subjects;

- studies using single photon absorptiometry to measure bone mass gains/losses.

The following information was extracted from each study: skeletal regions measured; experi- mental training protocol; training parameters including intensity, frequency and duration; and objective outcomes. This information was tabulated according to the experimental training protocol used and study design (cross-sectional or longitudinal studies). Studies that used more than one type of training protocol were included. The results of these studies were extracted and are summarized according to sex, study design and different life-stages: (i) young women and men; (ii) premenopausal women and middle-aged men; and (iii) older women and men.

\section{Experiments with Animals}

Using animal in vivo models - in which mechanical loads have been specifically applied to the rat tibia, ${ }^{[65]}$ rat tail, ${ }^{[66]}$ rat ulna $^{[67]}$ and avian bone $^{[37]}$ - it has been shown that the effects of mechanical loading are dependent upon the magnitude, duration and frequency of the mechanical stimulus applied. ${ }^{[68]}$ However, exercise not only consists of generation of mechanical loads, it also perturbs acid-base balance, stimulates sympathetic activity and influences production of several hormones, cytokines and adipokynes with known effects on bone metabolism. ${ }^{[69-73]}$ Thus, information provided by in vivo mechanical models should be combined with the information gained with exercise models, bearing in mind that the response to exercise may differ between animal species and that it is affected by other factors such as age, sex, nutrition and genetics.

The use of animal models to study bone adaptation to exercise is based on the fact that similar mechanisms control bone formation and resorption in animals and humans. ${ }^{[74]}$ Experiments with rats have shown that running has osteogenic effects on loaded bones of young male ${ }^{[75]}$ and female ${ }^{[76,77]}$ rats, as well as in ovariecto$\operatorname{mized}^{[78]}$ and orchidectomized rats, ${ }^{[79]}$ although the osteogenic effect of exercise appears to be less efficient in female ovariectomized rats. ${ }^{[78]}$ The forces generated during running play a role in the osteogenic response, since the rats that run with a loaded backpack on top of their back show a greater gain in bone mass than the rats running without extra load. ${ }^{[80]}$ In contrast, running 
at $80 \%$ of maximal oxygen load $\left(\dot{\mathrm{VO}}_{2 \max }\right)$ reduced longitudinal bone growth and induced bone loss, mainly due to decreased osteoblastic activity, in 5-week-old male rats $^{[81]}$ (table I). From these studies, it can be concluded that treadmill running may be useful to increase bone mass in young and adult rats of both sexes, especially in appendicular long bones at weightbearing sites; however, the increase in lumbar bone mass is absent or only detectable when longterm exercise is applied. ${ }^{[82]}$ However, these studies should be interpreted cautiously, since rats do not stop growing throughout their lifespan. Also, in contrast to what is observed in humans, longitudinal bone growth in adult rats increases after ovariectomy, and estrogen replacement inhibits this growth. ${ }^{[83]}$

In postpubertal female rats, bone is less responsive to loading than in ovariectomized rats or male rats of similar age. ${ }^{[84]}$ Jarvinen et al. ${ }^{[84]}$ have raised the question about the efficiency of bone loading during the estrogen-replete period in women, i.e. between puberty and menopause. Cross-sectional and observational longitudinal studies do indeed show a higher responsiveness to loading in human female bone when regular exercise starts before puberty than in adult life. ${ }^{[59,60,85]}$

\section{Studies with Humans}

\subsection{Cross-Sectional Studies}

In this section, recent cross-sectional studies measuring bone mass and/or BMD in recreational or professional athletes and sedentary adult women and men are reviewed, focusing on the osteogenic response to training as well as sex differences in the osteogenic response to training (table II). This issue has been previously reviewed by others, ${ }^{[22,94-97]}$ and only some representative studies are commented on in this section.

Inference from animal studies to humans ${ }^{[63]}$ implies that strength training, instead of endurance training programmes such as running, should result in the greatest increase in skeletal density. Focusing our attention on the early stage of life, girls and adolescents who spend more time training than is proposed by physical activity curricula $(<2 \mathrm{~h} / \mathrm{wk}$ in most European countries) achieve better peak bone mass, especially if they start before the pubertal growth spurt. ${ }^{[57,58]}$ Cross-sectional studies including sports participation and dual-energy x-ray absorptiometry (DXA) measurement at prepubertal ages show different results depending on the intensity and rate of the strains elicited. High strain-eliciting sports like gymnastics, which is thought to generate ground reaction forces close to ten times body mass in prepubertal children, ${ }^{[98]}$ report $5.7 \%$ higher mean upper extremities BMD compared with sedentary subjects in 9-year-old girls. ${ }^{[49]}$

Weight-bearing physical activities also improve bone mass in prepubertal subjects. In 9-year-old boys, soccer (football) practice ( $3 \mathrm{~h} / \mathrm{wk}$ ) has been associated with increased BMD compared with non-physically active boys at the lower limbs $(\uparrow 4 \%)$, lumbar spine $(\uparrow 2 \%)$, and femoral neck $(\uparrow 5 \%){ }^{[47,51,92]}$ Similarly, premenarchial girls enrolled in handball practice showed enhanced BMC and BMD at the lumbar spine, pelvic region and lower extremities; they also showed greater BMC in the whole body and enhanced BMD in the right upper extremity and femoral neck than the control subjects. ${ }^{[48]}$

In these sports, the potential osteogenic forces acting on the appendicular and axial bones are elicited by the high ground reaction forces evoked during jumping, kicking, sprinting, rapidly changing direction, starting, stopping, throwing, fall landings and blocks during defensive actions. Sports like swimming or rowing, without the action of gravitational forces, are beneficial for physical fitness but do not appear to have osteogenic benefits. ${ }^{\left[{ }^{[7,99]}\right.}$ Swimmers, like astronauts, ${ }^{[100]}$ operate in a low-gravity environment, with minimal impact on bone structures, and only relatively low tensions are transmitted by the muscular system to the bones during this type of exercise. This could explain why exercising in water early in life and regularly during the lifespan might abolish the osteogenic effect of sport.

\subsubsection{Young Men}

Studies performed in our laboratory have reported that adult (19-27 years old) amateur male 


\begin{tabular}{|c|c|c|c|c|c|c|c|c|c|}
\hline \multirow[t]{2}{*}{ Study } & \multicolumn{3}{|l|}{ Subjects } & \multirow[t]{2}{*}{ Frequency } & \multirow{2}{*}{$\begin{array}{l}\text { Training } \\
\text { intensity }\end{array}$} & \multirow{2}{*}{$\begin{array}{l}\text { Protocol } \\
\text { time }\end{array}$} & \multirow[t]{2}{*}{ Other } & \multicolumn{2}{|l|}{ Bone } \\
\hline & $\mathrm{n}$ & $\mathrm{M} / \mathrm{F}$ & age (wk) & & & & & measurement site (s) & results \\
\hline $\begin{array}{l}\text { Barengolts et al. }{ }^{[78]} \\
\text { (1993) }\end{array}$ & $\begin{array}{l}\mathrm{OXE}=20 \\
\mathrm{OXS}=20\end{array}$ & $\mathrm{~F}$ & 36 & $\begin{array}{l}4 / \mathrm{wk} \\
40 \mathrm{~min} / \text { day }\end{array}$ & $21 \mathrm{~m} / \mathrm{min}$ & $3 \mathrm{mo}$ & $\begin{array}{l}7 \% \text { grade treadmill } \\
\text { Ovariectomized rats }\end{array}$ & $\begin{array}{l}\text { DXA femur, } \\
\text { tibia, L4 }\end{array}$ & $\begin{array}{l}\text { Prevention of bone } \\
\text { loss }\end{array}$ \\
\hline $\begin{array}{l}\text { Hagihara et al. }{ }^{[77]} \\
(2005)\end{array}$ & $\begin{array}{l}E R=5 \\
E R 2=5 \\
E R 3=5 \\
C=5\end{array}$ & $\mathrm{~F}$ & 8 & $\begin{array}{l}4-7 / \mathrm{wk} \\
30 \mathrm{~min} / \text { day }\end{array}$ & $15 \mathrm{~m} / \mathrm{min}$ & $8 w k$ & & $\begin{array}{l}\text { QTC-trabecular L2, } \\
\text { tibia, femur }\end{array}$ & $\begin{array}{l}\uparrow L 2, \text { tibia, femur } \\
\text { ER, vs C }\end{array}$ \\
\hline $\begin{array}{l}\text { Bourrin et al. }{ }^{[75]} \\
\text { (1995) }\end{array}$ & $E R=20$ & M & 9 & 7/wk & $60 \% \dot{\mathrm{VO}}_{2 \max }$ & $5 w k$ & & HPC-tibia & $\begin{array}{l}\uparrow 27 \% \text { volume } \\
\uparrow 8 \% \text { trabeculae }\end{array}$ \\
\hline $\begin{array}{l}\text { Bourrin et al. }{ }^{[81]} \\
\text { (1994) }\end{array}$ & $E R=20$ & M & 5 & $7 / \mathrm{wk}$ & $80 \% \dot{\mathrm{VO}}_{2 \max }$ & $11 \mathrm{wk}$ & & HPC-tibia, L2, T2 & $\begin{array}{l}\downarrow \text { volume } \\
\downarrow \text { trabeculae }\end{array}$ \\
\hline $\begin{array}{l}\text { Horcajada et al. }{ }^{[79]} \\
\text { (1997) }\end{array}$ & $\begin{array}{l}\mathrm{SHE}=20 \\
\mathrm{CXE}=20 \\
\mathrm{C}=20\end{array}$ & M & 6 & $\begin{array}{l}\text { 7/wk } \\
15-60 \mathrm{~min} / \text { day }\end{array}$ & $\begin{array}{l}15-60 \mathrm{~m} / \min \\
60 \% \dot{\mathrm{VO}}_{2 \max }\end{array}$ & $3 \mathrm{mo}$ & $\begin{array}{l}\text { Orchidectomized } \\
\text { rats }\end{array}$ & DXA-femur & $\begin{array}{l}\uparrow \text { femur BMD in } \\
\text { CXE, SHE vs C }\end{array}$ \\
\hline $\begin{array}{l}\text { Yeh et al. }{ }^{[76]} \\
(1993)\end{array}$ & $\begin{array}{l}E R=28 \\
D R=24 \\
C=30\end{array}$ & $\mathrm{~F}$ & 6 & $5 / w k$ & $20 \mathrm{~m} / \mathrm{min}$ & $6 w k$ & Denervated rats & HPC-tibia & $\begin{array}{l}\uparrow \text { cortical bone } \\
\text { area in ER vs DR, C }\end{array}$ \\
\hline $\begin{array}{l}\text { Van der Wiel et al. }{ }^{[80]} \\
\text { (1995) }\end{array}$ & $\begin{array}{l}E R 1=10 \\
E R 2=10 \\
E R 3=10 \\
C=14\end{array}$ & $\mathrm{~F}$ & 20 & $5 / w k$ & $20 \mathrm{~m} / \mathrm{min}$ & $17 w k$ & $\begin{array}{l}\text { ER1: no extra load } \\
30 \mathrm{~min} \\
\text { ER2: } 5030 \mathrm{~g} \\
\text { load } 30 \mathrm{~min} \\
\text { ER3: } 50 \mathrm{~g} \text { load } 15 \mathrm{~min}\end{array}$ & DXA-WB, LL & $\begin{array}{l}\uparrow 16 \% \text { LL BMD } \\
\text { ER } 1 \text { vs C } \\
\uparrow 15 \% \text { LL BMD } \\
\text { ER } 2 \text { vs C } \\
\uparrow 15 \% \text { WB, } 20 \% \text { LL } \\
\text { BMD ER3 vs C }\end{array}$ \\
\hline
\end{tabular}


Table II. Effects of sports training on bone tissue adaptations in young adult men and women: cross-sectional studies

\begin{tabular}{|c|c|c|c|c|c|c|c|c|c|}
\hline \multirow[t]{2}{*}{ Study } & \multicolumn{5}{|l|}{ Subjects } & \multirow[t]{2}{*}{ Sport } & \multirow{2}{*}{$\begin{array}{l}\text { Bone } \\
\text { measurement } \\
\text { site (s) DXA }\end{array}$} & \multicolumn{2}{|l|}{ results } \\
\hline & $\mathrm{n}$ & $\mathrm{M} / \mathrm{F}$ & $\begin{array}{l}\text { age } \\
(\mathrm{y})\end{array}$ & $\begin{array}{l}\text { sports history; } \\
\text { mean time (y) }\end{array}$ & $\begin{array}{l}\text { training volume } \\
\text { (mean time) }\end{array}$ & & & $\mathrm{BMD}$ & BMC \\
\hline \multicolumn{10}{|l|}{ Young men } \\
\hline $\begin{array}{l}\text { Calbet et al. }{ }^{[86]} \\
\text { (2001) }\end{array}$ & $\begin{array}{l}E X=33 \\
C=19\end{array}$ & $M$ & $19-27$ & $E X=12$ & $7 \mathrm{~h} / \mathrm{wk}$ & Soccer & $\begin{array}{l}\text { WB, SP, FN, } \\
\text { IT, GT, WT, WL }\end{array}$ & $\begin{array}{l}\uparrow 10 \% \text { SP vs C } \\
\uparrow 21 \% \text { FN vs C } \\
\uparrow 19 \% \text { IT vs C } \\
\uparrow 21 \% \text { GT vs C } \\
\uparrow 27 \% \text { WT vs C } \\
\uparrow 10 \% \text { WL vs C }\end{array}$ & $\begin{array}{l}\uparrow 13 \% \text { WB vs C } \\
\uparrow 13 \% \text { SP vs } C \\
\uparrow 24 \% \text { FN vs } C \\
\uparrow 18 \% \text { IT vs } C \\
\uparrow 23 \% \text { GT vs } C \\
\uparrow 24 \% \text { WT vs } C \\
\uparrow 16 \% \text { WL vs C }\end{array}$ \\
\hline $\begin{array}{l}\text { Morel et al. }{ }^{[87]} \\
(2001)\end{array}$ & $\begin{array}{l}\mathrm{REX}=126 \\
\mathrm{RGB}=110 \\
\mathrm{FS}=44 \\
\mathrm{BB}=28 \\
\mathrm{SW}=14\end{array}$ & $M$ & $25-40$ & $\begin{array}{l}\mathrm{REX}=22 \\
\mathrm{RGB}=15 \\
\mathrm{FS}=18 \\
\mathrm{BB}=16 \\
\mathrm{SW}=11\end{array}$ & $\begin{array}{l}8.1 \mathrm{~h} / \mathrm{wk} \\
8.7 \mathrm{~h} / \mathrm{wk} \\
9.1 \mathrm{~h} / \mathrm{wk} \\
8.1 \mathrm{~h} / \mathrm{wk} \\
8.7 \mathrm{~h} / \mathrm{wk}\end{array}$ & $\begin{array}{l}\text { Running } \\
\text { Rugby } \\
\text { Fighting } \\
\text { Body-building } \\
\text { Swimming }\end{array}$ & $\begin{array}{l}\text { WB, A, WL, } \\
\text { SP, S }\end{array}$ & $\begin{array}{l}\uparrow 10 \% \text { WB RGB vs OS } \\
\uparrow 2 \% \text { WB FS vs OS } \\
\uparrow 2 \% \text { WB BB vs OS } \\
\downarrow 8 \% \text { WB SW vs OS } \\
\uparrow 5 \% \text { A RGB vs OS } \\
\uparrow 4 \% \text { A FS vs OS } \\
\uparrow 9 \% \text { WL RGB vs OS } \\
\uparrow 1 \% \text { WL FS vs OS } \\
\downarrow 5 \% \text { WL BB vs OS }\end{array}$ & \\
\hline $\begin{array}{l}\text { Calbet et al. }{ }^{[88]} \\
(1998)\end{array}$ & $\begin{array}{l}E X=9 \\
C=13\end{array}$ & $M$ & $21-32$ & $E X=17$ & $25 \mathrm{~h} / \mathrm{wk}$ & Tennis & $\begin{array}{l}\text { WB, A, SP, FN, } \\
\text { WT, WL }\end{array}$ & $\begin{array}{l}\uparrow 15 \% \text { SP EX vs C } \\
\uparrow 10-15 \% \text { FN EX vs C }\end{array}$ & $\uparrow 5 \%$ DAP vs NDAP \\
\hline $\begin{array}{l}\text { Wittich et al. }{ }^{[89]} \\
\text { (1998) }\end{array}$ & $\begin{array}{l}E X=24 \\
C=22\end{array}$ & $M$ & $20-24$ & $\mathrm{EX}=8$ & $20 \mathrm{~h} / \mathrm{wk}$ & Soccer & WB, WL, PR & $\begin{array}{l}\uparrow 11 \% \text { WB vs C } \\
\uparrow 14 \% \mathrm{PR} \text { vs C } \\
\uparrow 14 \% \mathrm{WL} \text { vs } \mathrm{C}\end{array}$ & $\begin{array}{l}\uparrow 15 \% \text { WB vs C } \\
\uparrow 25 \% \text { PR vs C } \\
\uparrow 20 \% \text { WL vs C }\end{array}$ \\
\hline \multicolumn{10}{|l|}{ Young women } \\
\hline $\begin{array}{l}\text { Egan et al. }{ }^{[90]} \\
(2006)\end{array}$ & $\begin{array}{l}\mathrm{REX}=11 \\
\mathrm{RGB}=30 \\
\mathrm{NB}=20 \\
\mathrm{C}=25\end{array}$ & $\mathrm{~F}$ & $19-23$ & $\begin{array}{l}\mathrm{REX}=9 \\
\mathrm{RGB}=4 \\
\mathrm{NB}=4\end{array}$ & $\begin{array}{l}8.4 \mathrm{~h} / \mathrm{wk} \\
4.1 \mathrm{~h} / \mathrm{wk} \\
3.7 \mathrm{~h} / \mathrm{wk}\end{array}$ & $\begin{array}{l}\text { Running } \\
\text { Rugby } \\
\text { Netball }\end{array}$ & WB, SP, LPF & $\begin{array}{l}\uparrow \text { WB all sports vs C } \\
\uparrow 13.5 \% \text { RGB WB vs C } \\
\uparrow 16.5 \% \text { SP RGB vs C } \\
\uparrow 21.7 \% \text { FN RGB vs C }\end{array}$ & \\
\hline $\begin{array}{l}\text { Nichols et al.. }{ }^{[1]} \\
(2007)\end{array}$ & $\begin{array}{l}\operatorname{HOAEX}=21 \\
\mathrm{HEX}=72 \\
\operatorname{ROAEX}=17 \\
\operatorname{RNEX}=51\end{array}$ & $\mathrm{~F}$ & $14-16$ & $\begin{array}{l}\text { HOAEX; } \\
\text { HEX }=6.5 \\
\text { ROAEX; } \\
\text { RNEX }=6.1\end{array}$ & $\begin{array}{l}8.6 \mathrm{~h} / \mathrm{wk} \\
8.5 \mathrm{~h} / \mathrm{wk}\end{array}$ & $\begin{array}{l}\text { Soccer, } \\
\text { volleyball, } \\
\text { softball, tennis, } \\
\text { lacrosse, } \\
\text { running, } \\
\text { swimming }\end{array}$ & $\begin{array}{l}\text { WB, SP, WH, } \\
\text { FN, GT }\end{array}$ & $\begin{array}{l}\uparrow 4 \% \text { HEX WH vs } \\
\text { HOAEX } \\
\uparrow 7 \% \text { HEX GT vs } \\
\text { HOAEX } \\
\uparrow 10 \% \text { HEX LS vs } \\
\text { ROAEX } \\
\uparrow 5 \% \text { HEX LS vs } \\
\text { ROAEX }\end{array}$ & \\
\hline
\end{tabular}




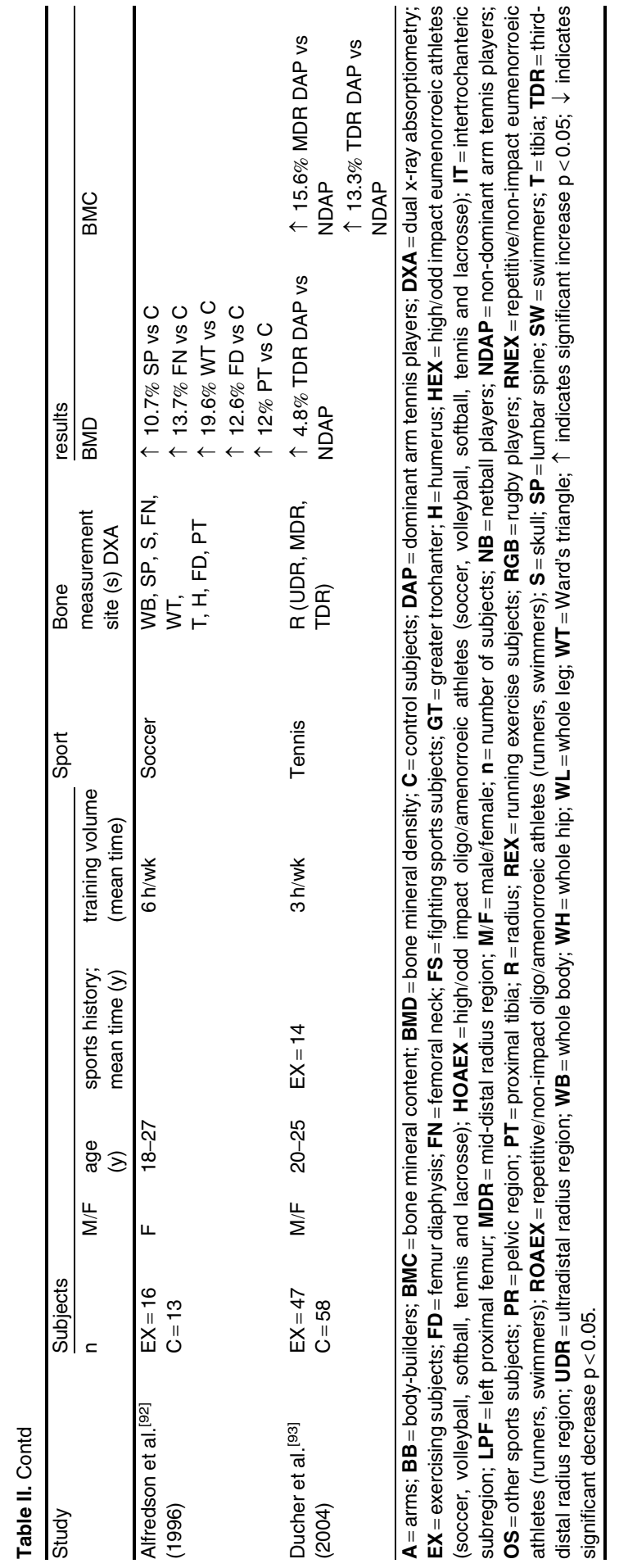

soccer players with a long training history (mean 12 years) have increased BMC and BMD at the lumbar spine (13\% and $10 \%$ respectively), femoral neck (24\% and $21 \%$ ) and lower limbs (16\% and $10 \%)$ compared with age-, height- and weight-matched sedentary controls of the same Caucasian population. ${ }^{[86]}$ Similar results were reported by Wittich et al. ${ }^{[89]}$ in 20 - to 22 -year-old soccer players. These adaptations are likely elicited by the ground reaction forces generated during jumping and sprinting with sudden changes in the direction of movement, combined with the high strains elicited during kicking. ${ }^{[101,102]}$

With relatively low volumes of exercise (2-3 hours) per week it is possible to elicit increases in $\mathrm{BMC}$ and BMD in the loaded bones of prepubertal tennis players (Sanchis et al., unpublished observations). The magnitude of the local adaptation elicited by tennis participation is further enhanced for training volumes above $7 \mathrm{~h} / \mathrm{wk}$ (Sanchis et al., unpublished observations). A direct comparison of prepubertal soccer players $^{[51]}$ or tennis players with professional adult players $^{[86,88]}$ indicates that part of the bone mass gained through sports participation is achieved before puberty. In contrast, compared with sedentary peers, a $20 \%$ lower lumbar spine BMC has been reported in 19- to 56-year-old longdistance runners performing a training volume close to $100 \mathrm{~km} /$ week. ${ }^{[103]}$

Morel et al. ${ }^{[87]}$ examined the influence of regular exercise (mean $9 \mathrm{~h} / \mathrm{wk}$ ) on BMD in 403 non-professional male subjects aged 30 years involved in different sports. This is an ideal age to compare BMD measurements because peak bone mass has been already reached and bone loss is still insignificant. Soccer, basketball, volleyball, gymnastics, weight-lifting and ice hockey were associated with a higher whole body BMD (WBBMD) whereas rowers and especially swimmers had a WBBMD similar to that of a sedentary group. Regional BMD comparison suggested that there may be site-specific responses due to the specific types of mechanical loading exerted through physical activity, because sportsmen involved in impact-loading sports (i.e. fighting sports) had a higher leg BMD than those in active loading sports (i.e. body-building) [see table II]. 
In the upper limbs the positive effect of mechanical loading via musculotendinous attachments is demonstrated in racquet sports such as tennis $^{[88,104]}$ and squash. ${ }^{[105]}$ The asymmetrical nature of racket sports offers an interesting model to study the adaptability of both the skeletal and soft tissue of the upper limbs to physical stress, using the non-dominant arm as a control. Based on a side-to-side comparison, these studies enabled elimination of the confounding effects of genetic, hormonal and nutritional factors that are encountered in cross-sectional studies. ${ }^{[104]}$ Elite young tennis players (mean age 26 years), with a high training load of $25 \mathrm{~h} / \mathrm{wk}$, show enhanced BMC (20\%) and BMD (6\%) in the dominant arm compared with the contralateral arm. These tennis players also had increased (10-15\%) femoral neck and lumbar spine BMD compared with controls. ${ }^{[88]}$ Similar effects have been described in the mid- and third-distal radius in young adult male and female recreational tennis players. ${ }^{[106]}$

\subsubsection{Young Women}

Second division female soccer players (aged 18-24 years) show bone adaptations similar to those reported in males, ${ }^{[92]}$ with $11 \%, 15 \%$ and $20 \%$ higher BMD at lumbar spine, femoral neck and Ward's triangle, and $8-13 \%$ higher BMD at the non-dominant femur and humerus, distal femur and proximal tibia compared with non-physically active women (table II).

Egan et al. ${ }^{[90]}$ compared BMD and body composition among young female athletes (rugby players, distance runners and netball players) with a mean age of 21 years versus sedentary control subjects. All sports groups had higher BMD values than the controls, but rugby players had the greatest BMD values at the lumbar spine $(\uparrow 16.5 \%)$, femoral neck $(\uparrow 21.7 \%)$ and hip ( $\uparrow 13.5 \%)$. Moreover, significant correlations were observed between BMD and fat-free soft tissue mass, BMD and body mass, and BMD and training volume.

Menstrual status has a major influence in the osteogenic response to exercise. ${ }^{[96]}$ Cross-sectional data indicate that female oligo-/amenorrhoeic high school athletes (mean age 16 years) practicing impact sports may not be accruing the same bone mass as their eumenorrhoeic counterparts. ${ }^{\left[{ }^{[1]}\right.}$

In summary, when normal menstrual status is reported in women, both sexes seem to benefit equally from sport participation (table II): the mean gains for total body BMD are about $10 \%$, reaching $15-20 \%$ in the sport-specific loaded sites. According to the training load and intensity, athletes who train more $(20 \mathrm{~h} / \mathrm{wk}$ approximately) achieve greater bone mass gains. However, recreational athletes also benefit from a 5- to 6-h/wk training volume. If not accompanied by menstrual disturbances, high training volumes do not seem to negatively affect the osteogenic adaptive response to loading. Most studies report that the osteogenic response to exercise is specific to the loaded bones, and sports with higher impact and ground reaction forces elicit superior osteogenic responses. These effects are more marked in athletes who began their sport participation close to the pubertal growth spurt. ${ }^{[107-109]}$

Cross-sectional investigations are suggestive of a relationship between training and bone metabolism; however, these studies compared independent samples and therefore were not able to establish a causal relationship between the variables of interest. In fact part of the effects described in the participants of different sports may have been caused by selection bias. Girls or boys with a larger musculoskeletal size and bone mass, ${ }^{[10]}$ due to inherited characteristics, may choose to exercise because they may be more likely to be successful in competition and feel more rewarded by exercise practice. To rule out such a possibility, longitudinal studies and randomized clinical control trials are necessary.

\subsection{Longitudinal Studies}

Although evidence is accumulating suggesting that childhood is the best period of life to obtain osteogenic benefits from physical activity, modern children (especially girls) have become increasingly sedentary. ${ }^{[111,112]}$ In addition, girls experience the pubertal growth spurt 1-2 years before boys do, ${ }^{[113]}$ meaning that they should start regular activity even sooner than boys to 
achieve the full osteogenic benefit from physical activity.

The strength of longitudinal studies is that randomized study designs reduce self-selection in group assignment, which is particularly important in exercise trials where individuals may be more or less predisposed to participate in physical activity. The majority of these studies have been performed in women. There are few longitudinal studies testing the response of men and women to the same training programme. A review of recent longitudinal studies performed with young adult men and women is depicted in table III.

\subsubsection{Young Women}

Peak bone mass is thought to be attained by the end of the third decade of life, therefore the early adult years may be the final opportunity for its augmentation. ${ }^{[127]}$ As summarized previously in this review, athletes involved in high impact sports have higher bone mass than other athletes; consequently, longitudinal exercise programmes including exercises eliciting high impacts and forces on bones should evoke greater accumulation of bone mass and enhancement of BMD. However, the findings of studies performed in young adults have not consistently produced these findings. Standard resistance-training protocols enhance muscle mass, ${ }^{[128-131]}$ and in several cases bone mass, ${ }^{[114,132]}$ in young women. Friedlander et al. ${ }^{[14]}$ reported significant increases after a 2-year programme of aerobics and weight-training in lumbar spine, intertrochanteric and calcaneal BMD. The addition of daily calcium supplementation did not add significant benefit to the intervention. ${ }^{[14]}$ Also, Snow-Harter et al. ${ }^{[133]}$ noted significant increases in lumbar BMD in young women completing either a progressive aerobic training programme (jogging) or a progressive resistance training programme, when compared with a control group. The resistance training group showed significant strength increases compared with the aerobictrained women; however, the increases in BMD were not significantly different between the two exercise groups. This result is consistent with the site-specific principles of mechanical loading, as both groups of women performed weight-bearing exercise, stressing the lower body and lumbar spine. Differences might not necessarily be expected between exercise groups in these studies due to the short duration of the protocol and the physiological limits of bone formation and remodelling. These conventional strength-training techniques involve both a concentric and an eccentric component. However, maximal skeletal muscle eccentric contractions develop greater tension than maximal concentric or isometric contractions, ${ }^{[134]}$ and the magnitude of the load associated with maximal eccentric contraction is responsible for significant increases in bone mass in young women. ${ }^{[116]}$ Schroeder et al. ${ }^{[115]}$ further investigated this topic by testing the hypothesis that young women participating in high-intensity eccentric resistance training would have significantly greater increases in lean body mass and muscle strength and improved bone adaptations compared with low-intensity eccentric resistance training. These authors reported that low-intensity eccentric training (ET; $75 \%$ of concentric 1 repetition maximum [RM]) was as effective as high-intensity training (125\% of a concentric $1 \mathrm{RM}$ ) and, surprisingly, there were no significant alterations in bone mass in the high-intensity group. ${ }^{[15]}$ This finding is at odds with a previous study from this group reporting $3.9 \%$ greater BMD in the mid-femur after a similar ET protocol. ${ }^{[16]}$ ET both at low and high intensities has been associated with elevated concentrations of osteocalcin in conjunction with decreased crosslinks, which suggests osteogenesis combined with reduced bone resorption. ${ }^{[15]}$ Nickols-Richardson et al. ${ }^{[117]}$ studied the effects of unilateral leg and arm high-intensity strength training lasting 5 months in young women. One group underwent ET and other group underwent concentric training (CT), with non-trained limbs serving as controls. The two kinds of exercise were similarly effective for improving muscular strength and bone mass, and density with gains in WBBMC $(0.4 \%$ CT vs $0.6 \%$ ET), proximal femur BMD $(0.5 \% \mathrm{CT}$ vs $1.2 \% \mathrm{ET})$, total forearm BMD $(0.6 \% \mathrm{CT}$ vs $0.4 \% \mathrm{ET})$ and total forearm BMC (0.4\% CT vs $0.5 \%$ ET).

High impact training has also been demonstrated to yield positive results in young women..$^{[18,119]}$ 
Table III. Effects of training protocols on bone tissue adaptations in young and middle-aged women: longitudinal studies

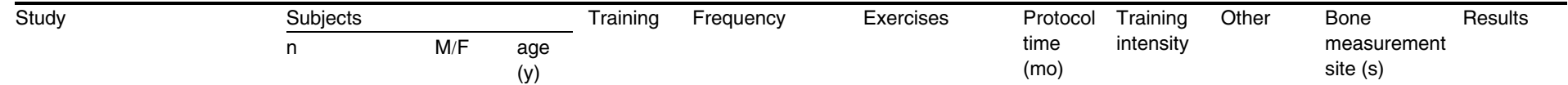

\section{Young women}

Friedlander et al. ${ }^{[14]}$

$\mathrm{EX}=63$

(mo)

site (s)

(1995)

Schroeder et al. ${ }^{[115]}$

$\mathrm{HRT}=14$

F 20-35

24

$1500 \mathrm{mg}$

(2004)

LRT $=14 C=9$

22-26 ERT

2/wk,

3 sets $\times 10$ rep

Seated chest 4

$125 \%$

$1 \mathrm{RM}$

LRT: $75 \%$

$\mathrm{Ca} / \mathrm{S}$

$\begin{array}{ll}\text { lat pulldown, } & \text { LRT: } 75 \% \\ \text { biceps curl, } & 1 \mathrm{RM} \\ \text { triceps } & \end{array}$

WB, SP, F $\quad$ 1.7\%

SPBMD in

LRT

extension,

single-leg

extension

double

leg curl

Hawkins et al. ${ }^{[16]}$

$\mathrm{EX}=8$

$\mathrm{C}=8$

19-23 CO-E RT 3/wk

Isokinetic knee

CO: 3 sets $\times 4$ rep flexion and

$\mathrm{E}: 3$ sets $\times 3$ rep extension

E: 1 RM

CO: 1 RM

WB, SP, F $\uparrow 3.9 \%$

FBMD in

ERT

$\uparrow$ FBMD

ERT vs C

Nickols-Richardson et al. ${ }^{[117]}$ EEX $=37$

F $\mathrm{COEX}=33$

18-26 UET

$3 /$ wk

and leg

resistance

$\mathrm{rep} / / \mathrm{limb} / \mathrm{session}$ training

MVE

WB, TPF, $\quad \uparrow 1.2 \%$

DT, TF WB, $5 \%$

TFBMC in

EEX

$\uparrow 1.1 \%$

TPF, $0.5 \%$

TFBMD in

EEX

$\uparrow 0.9 \%$

WB, $4 \%$

TFBMC in

COEX

$\uparrow 0.6 \% \mathrm{TF}$,

$0.5 \%$

TPFBMC in

COEX 


\begin{tabular}{|c|c|c|c|c|c|c|c|c|c|c|c|}
\hline \multirow[t]{2}{*}{ Study } & \multicolumn{3}{|l|}{ Subjects } & \multirow[t]{2}{*}{ Training } & \multirow[t]{2}{*}{ Frequency } & \multirow[t]{2}{*}{ Exercises } & \multirow{2}{*}{$\begin{array}{l}\text { Protocol } \\
\text { time } \\
(\mathrm{mo})\end{array}$} & \multirow{2}{*}{$\begin{array}{l}\text { Training } \\
\text { intensity }\end{array}$} & \multirow[t]{2}{*}{ Other } & \multirow{2}{*}{$\begin{array}{l}\text { Bone } \\
\text { measurement } \\
\text { site (s) }\end{array}$} & \multirow[t]{2}{*}{ Results } \\
\hline & $\mathrm{n}$ & $\mathrm{M} / \mathrm{F}$ & $\begin{array}{l}\text { age } \\
\text { (y) }\end{array}$ & & & & & & & & \\
\hline Kato et al. ${ }^{[118]}(2006)$ & $\begin{array}{l}E X=18 \\
C=18\end{array}$ & $\mathrm{~F}$ & $20-22$ & HIT & $\begin{array}{l}3 / \text { wk } \\
1 \text { set } \times 10 \text { rep }\end{array}$ & $\begin{array}{l}\text { Counter- } \\
\text { movement } \\
\text { jumps }\end{array}$ & 6 & MVE & $\begin{array}{l}300 \mathrm{mg} \\
\mathrm{Ca} / \mathrm{S} \text { in } \\
\mathrm{EX}, \mathrm{C}\end{array}$ & $\begin{array}{l}\text { SP, FN, } \\
\text { GT, WT }\end{array}$ & $\begin{array}{l}\text { 个 } 2.6 \% \\
\text { FN, } 2.4 \% \\
\text { SPBMD in } \\
\text { EX }\end{array}$ \\
\hline Bassey et al. ${ }^{[119]}$ (1994) & $\begin{array}{l}E X=14 \\
C=13\end{array}$ & $\mathrm{~F}$ & $27-34$ & HIT & $3 /$ wk & $\begin{array}{l}\text { Jumping, } \\
\text { skipping }\end{array}$ & 12 & MVE & & $\begin{array}{l}\text { R, SP, FN, } \\
\text { GT, WT }\end{array}$ & $\begin{array}{l}\uparrow 4.1 \% \\
\text { GTBMD in } \\
\text { EX }\end{array}$ \\
\hline Sinaki et al..[120] (1996) & $\begin{array}{l}E X=60 \\
C=60\end{array}$ & $\mathrm{~F}$ & $30-40$ & RT & $\begin{array}{l}3 / \text { wk } \\
3 \text { sets } \times \\
10 \text { rep }\end{array}$ & $\begin{array}{l}\text { Back extension } \\
\text { and shoulder } \\
\text { girdle weight- } \\
\text { lifting exercises }\end{array}$ & 36 & $\begin{array}{l}50-100 \% \\
10 \mathrm{RM}\end{array}$ & $\begin{array}{l}\text { Physically } \\
\text { active } \\
\text { women }\end{array}$ & $\begin{array}{l}\text { WB, SP, } \\
\text { WH, R }\end{array}$ & NC \\
\hline Chilibeck et al. ${ }^{[121]}$ (1996) & $\begin{array}{l}E X=20 \\
C=10\end{array}$ & $\mathrm{~F}$ & $19-21$ & $\mathrm{RT}+\mathrm{ET}$ & $2 / w k$ & $\begin{array}{l}\text { Arm curl, } \\
\text { bench press, } \\
\text { leg press }\end{array}$ & 4.5 & & & $\begin{array}{l}\text { WB, SP, L, A, } \\
\text { FN, WT, GT, } \\
\text { IT }\end{array}$ & NC \\
\hline Nindl et al. ${ }^{[122]}(2000)$ & $\begin{array}{l}E X=26 \\
C=5\end{array}$ & $\mathrm{~F}$ & $24-32$ & RT & $\begin{array}{l}5 / \text { wk } \\
4-6 \text { set } \times \\
10-12 \text { rep }\end{array}$ & $\begin{array}{l}\text { Squat, bench } \\
\text { press, sit up, leg } \\
\text { curl, row with } \\
\text { elbows low } \\
\text { + aerobics }\end{array}$ & 6 & & & WB, L, A, Tr & $\mathrm{NC}$ \\
\hline \multicolumn{12}{|l|}{ Premenopausal women } \\
\hline Lohman et al.. ${ }^{[23]}$ (1995) & $\begin{array}{l}E X=22 \\
C=34\end{array}$ & $\mathrm{~F}$ & 28-39 & RT & $\begin{array}{l}3 / \text { wk } \\
3 \text { sets } \times \\
8-12 \text { rep }\end{array}$ & $\begin{array}{l}\text { Bicep curl, } \\
\text { bench press, } \\
\text { supine flys, } \\
\text { lat pulldown, } \\
\text { leg curl, leg } \\
\text { extension, leg } \\
\text { press, military } \\
\text { press, low rows, } \\
\text { right wrist curl }\end{array}$ & 18 & $\begin{array}{l}75-80 \% \\
1 \mathrm{RM}\end{array}$ & $\begin{array}{l}500 \mathrm{mg} \\
\mathrm{Ca} / \mathrm{S} \text { in } \\
\mathrm{RT}, \mathrm{C}\end{array}$ & $\begin{array}{l}\text { WB, SP, FN, } \\
A, L\end{array}$ & $\begin{array}{l}\uparrow \text { SPBMD } \\
\text { in EX } \\
\uparrow \text { FNBMD } \\
\text { in EX }\end{array}$ \\
\hline & & & & & & & & & & \multicolumn{2}{|c|}{ Continued next page } \\
\hline
\end{tabular}




\begin{tabular}{|c|c|c|c|c|c|c|c|c|c|c|c|}
\hline \multirow[t]{2}{*}{ Study } & \multicolumn{3}{|l|}{ Subjects } & \multirow[t]{2}{*}{ Training } & \multirow[t]{2}{*}{ Frequency } & \multirow[t]{2}{*}{ Exercises } & \multirow{2}{*}{$\begin{array}{l}\text { Protocol } \\
\text { time } \\
(\mathrm{mo})\end{array}$} & \multirow{2}{*}{$\begin{array}{l}\text { Training } \\
\text { intensity }\end{array}$} & \multirow[t]{2}{*}{ Other } & \multirow{2}{*}{$\begin{array}{l}\text { Bone } \\
\text { measurement } \\
\text { site (s) }\end{array}$} & \multirow[t]{2}{*}{ Results } \\
\hline & $n$ & $\mathrm{M} / \mathrm{F}$ & $\begin{array}{l}\text { age } \\
\text { (y) }\end{array}$ & & & & & & & & \\
\hline $\begin{array}{l}\text { Vainionpää et al.. }{ }^{[24]} \\
\text { (2005) }\end{array}$ & $\begin{array}{l}E X=39 \\
C=41\end{array}$ & $\mathrm{~F}$ & $35-40$ & HIT & $3 / w k$ & $\begin{array}{l}\text { Step patterns, } \\
\text { stamping, } \\
\text { jumping, } \\
\text { running, walking }\end{array}$ & 12 & MVE & & $\begin{array}{l}\text { SP, F, FN, } \\
\text { IT, DF. }\end{array}$ & $\begin{array}{l}\uparrow 1.1 \\
\text { FNBMD EX } \\
\text { vs C } \\
\uparrow 0.8 \\
\text { ITBMD EX } \\
\text { vs } C \\
\uparrow 0.1 \\
\text { FBMD EX } \\
\text { vs C } \\
\uparrow 2.2 \\
\text { L1BMD EX } \\
\text { vs C }\end{array}$ \\
\hline
\end{tabular}

\begin{tabular}{|c|c|c|c|c|c|c|c|c|c|c|}
\hline $\begin{array}{l}\text { Winters-Stone and Snow }{ }^{[125]} \\
(2006)\end{array}$ & $\begin{array}{l}\text { LEX }=19 \\
\text { ULEX }=16 \\
C=24\end{array}$ & $F$ & $34-44$ & $\mathrm{RT}+\mathrm{HIT}$ & $\begin{array}{l}3 / \text { wk } \\
3-9 \text { sets } x \\
8-12 \text { rep }\end{array}$ & $\begin{array}{l}\text { LEX: jumps, } \\
\text { squat, lunges, } \\
\text { calf raises } \\
\text { ULEX: } \\
\text { LEX + upright } \\
\text { row, one-arm } \\
\text { row, lat dorsi pull } \\
\text { down, chest } \\
\text { press, chest fly, } \\
\text { biceps curl, } \\
\text { triceps } \\
\text { extension }\end{array}$ & 12 & $\begin{array}{l}\uparrow 0-13 \% \\
\text { BW }\end{array}$ & $\begin{array}{l}\text { WB, SP, FN, } \\
\text { GT }\end{array}$ & $\begin{array}{l}\uparrow 2.6 \% \\
\text { GTBMD } \\
\text { ULEX vs C } \\
\uparrow 2.2 \% \\
\text { GTBMD } \\
\text { LEX vs C } \\
\uparrow 1.3 \% \\
\text { SPBMD } \\
\text { ULEX vs } 0\end{array}$ \\
\hline $\begin{array}{l}\text { Heinonen et al. }{ }^{[126]} \\
(1996)\end{array}$ & $\begin{array}{l}E X=49 \\
C=49\end{array}$ & $F$ & 35-45 & HIT & $3 / w k$ & $\begin{array}{l}\text { Jumping, } \\
\text { callisthenics }\end{array}$ & 18 & $\begin{array}{l}2-6 \text { times } \\
\text { BW }\end{array}$ & $\begin{array}{l}\text { SP, FN, GT, } \\
\text { TDF, R }\end{array}$ & $\begin{array}{l}\uparrow 1.6 \% \\
\text { FNBMD in } \\
\text { EX }\end{array}$ \\
\hline
\end{tabular}

$\mathbf{1 R M}=1$ repetition maximum; $\mathbf{A}=$ arms; $\mathbf{B M D}=$ bone mineral density; $\mathbf{C}=$ control subjects; $\mathbf{C a} / \mathbf{S}=$ supplemental calcium; $\mathbf{C O}-\mathbf{E} \mathbf{R T}=$ concentric-eccentric resistance training; COEX = concentric exercising subjects; $\mathbf{D F}=$ distal forearm; $\mathbf{D T}=$ distal tibia; $\mathbf{E E X}=$ eccentric exercising subjects; $\mathbf{E R T}=$ eccentric resistance training; $\mathbf{E T}=$ endurance training; EX = exercising subjects; FD = femur diaphysis; $\mathbf{F N}$ = femoral neck; $\mathbf{G T}=$ greater trochanter; $\mathbf{H I T}=$ high-impact training; $\mathbf{H R T}=$ high-intensity eccentric resistance training subjects; $\mathbf{I T}=$ intertrochanteric subregion; $\mathbf{L}=$ whole leg; $\mathbf{L} \mathbf{1}=$ first lumbar vertebra; lat=latissimus; $\mathbf{L E X}=$ lower body exercising subjects; $\mathbf{L R T}=$ low-intensity eccentric resistance training; $\mathbf{M} / \mathbf{F}=$ male/female; $\mathbf{M V E}=$ maximal voluntary effort; $\mathbf{n}=$ number of subjects; $\mathbf{N C}=$ no changes; $\mathbf{R}=$ radius; rep= repetition; $\mathbf{T r}=$ trunk; $\mathbf{R T}=$ resistance training; $\mathbf{S P}=$ lumbar spine; TDF = total distal femur; TF = total forearm; TPF = total proximal femur; UCT = unilateral concentric training; UET = unilateral eccentric training; ULEX = upper + lower body exercising subjects; WB $=$ whole body; $\mathbf{W H}=$ whole hip; $\mathbf{W T}=$ Ward's triangle; \%BW = percentage of bodyweight; $\uparrow$ indicates significant increase $\mathbf{p}<0.05$; $\downarrow$ indicates significant decrease $p<0.05$. 
Recently, Kato and co-workers ${ }^{[18,119]}$ tested the effect of a 6-month low repetition jump training programme (10 maximum vertical jumps/day, three times/week) on lumbar and hip BMD in young women (age 21 years). Despite the low number of jumps compared with other studies, based on jumping exercises in which subjects performed ten times more jumps per week, ${ }^{[119]}$ BMD increased significantly in both regions, whereas no changes were observed in the control group. Although more studies are needed, these results suggest that the bones of young women respond to low repetition as well as high repetition jump training.

On the other hand, resistance training has been reported to have either no effect or a negative impact on bone in a few studies in young women. ${ }^{[120-122]}$ Sinaki et al. ${ }^{[120]}$ found no significant effect of a 3-year non-strenuous, weightlifting exercise programme on BMD at lumbar spine, whole hip or mid-radius in active but not athletic premenopausal women $30-40$ years of age. A particularity of this study is that only two different exercises were used: back extension and shoulder girdle weight-lifting exercises (as defined by the authors). The back extension exercise session consisted of three sets of 10 RM performed once a day for 3 days per week (one supervised session each week at the medical centre) with back extension. The shoulder exercise programme was adjusted every 3 months following the sequence $50 \%$ of $10 \mathrm{RM}$ for the first month, $75 \%$ of $10 \mathrm{RM}$ for the second month, and $100 \%$ of $10 \mathrm{RM}$ for the third month, which was prior to the next visit and re-evaluation. ${ }^{[120]}$

Chilibeck et al. ${ }^{[121]}$ reported in 20-year-old women that after a 20 -week weight-lifting training period, which increased muscle strength $(23-73 \%)$ and lean tissue mass $(3-10 \%)$ in the trunk and the extremities, BMC and BMD failed to increase in whole body, arm, leg, ribs, thoracic and lumbar spine, and pelvis segments. Similarly, hip BMC and BMD at femoral neck, trochanter, intertrochanter and Ward's triangle sites and total hip did not increase with training. ${ }^{[121]}$ In 28-year-old women, no changes in whole body or regional bone mass and density were observed following a 24-week training programme com- bining weight-lifting with endurance exercise $(1.5 \mathrm{~h} /$ day for 5 days/wk), despite a $2.2 \%$ increase in whole body lean mass and a $5.5 \%$ increase in leg lean mass. ${ }^{[122]}$

To this point, the studies reviewed indicate that strength training needs to involve highintensity exercises to enhance bone mass in young women. The osteogenic effect may be attenuated if endurance exercise is carried out in combination with strength training, and enhanced if the strength training programme is combined with high impact exercises, like jumping.

Bone formation in weight-bearing regions of the skeleton can be stimulated by low-magnitude highfrequency strains, induced through vibration. ${ }^{[38,39]}$ In young women aged 15-20 years with low BMD, low level whole body vibration $(30 \mathrm{~Hz} ; 0.3 \mathrm{~g})$ applied daily (between 2 and 10 minutes) for 1 year increased cancellous bone in the lumbar vertebrae (2.1\%) and cortical bone in the femoral midshaft (3.4\%), respectively, measured by quantitative computer tomography (QCT), compared with controls. It is noteworthy that, in this study, these gains were not detected with DXA. ${ }^{[135]}$

\subsubsection{Young Men}

Randomized longitudinal studies on sedentary young men are scarce. A 4-month strength training programme (three times per week, at $60-80 \%$ of 1 RM) in Oriental men (aged 23-31 years) did not elicit changes in whole body or loaded bones BMC and BMD. However, serum osteocalcin and bone-specific alkaline phosphatase concentrations were increased 1 month after the start of the training, suggesting that bone markers are more efficient to detect changes in the bone remodelling than DXA. ${ }^{[136]}$ Hartman et al. ${ }^{[137]}$ did not find significant changes in WBBMC after 12 weeks of strength training (five times per week) in subjects who consumed fat-free milk, soy or carbohydrates after the training sessions despite substantial increases in lean body mass and strength. However, a regional analysis of BMD was not reported in that study. With 6 months of training (strength + aerobics) combined with either protein or carbohydrate supplementation, positive effects on $\mathrm{BMC}, \mathrm{BMD}$ and geometrical variables of the 
tibia measured by peripheral QCT have been reported in both young men and young women. ${ }^{[138]}$ In this study, all groups experienced significant increases in tibia cortical thickness and area, and decreased their endosteal circumference over the intervention period. Cortical thickness among females was greater if they were receiving supplemental protein, whereas among men the change was the greatest if they were receiving carbohydrate supplementation. No changes were observed on whole body measurements in any group. These results suggest that there may be sex-specific differences in the bone response to exercise when supplementing with protein. However, due to the absence of a non-exercising control group it is not clear if exercise was the responsible factor for the changes. This study contrasts with that of Ryan et al., ${ }^{[139]}$ who found no sex differences in the training response between men and women for any of the whole body, femoral neck and lumbar spine BMD measurements after a 6-month resistance training programme. The latter study is also affected by the lack of age- and sex-matched control groups.

We have not found long-duration (more than 6 months) randomized longitudinal studies on the effects of strength training on bone mass in sedentary young men.

\subsubsection{Premenopausal Women}

A long-term (18-month) randomized, controlled, prospective study with high-intensity resistance training in adult women indicated that regional BMD at the femoral neck and trochanteric sites can be increased by resistance training exercise. ${ }^{[123]}$ However, WBBMD did not change significantly over the 18 months of this trial, which could indicate that increases in strength and lean tissue may be greater than increases in BMD in premenopausal women and that in young women there may be a site-specific redistribution of BMD rather than a total body increase in BMC. ${ }^{[123]}$ This hypothesis is supported in other studies, which evaluated regional body composition changes in women after periodized physical training. ${ }^{[22,129-131,140]}$ Similarly, Vainionpää et al. ${ }^{[124]}$ noted significant BMD in- creases in femoral and lumbar sites in premenopausal women after a progressive 12-month high impact training (jumping) programme; WB was not measured in this study but calcaneal broadband ultrasound attenuation also showed a significant increase in the exercise group compared with the control group, ${ }^{[124]}$ suggesting enhanced bone quality. Winters-Stone and Snow ${ }^{[125]}$ also support the site-specific response of lumbar spine and hip BMD to upper and lower body resistance exercise training, found in two groups of nonactive premenopausal women (aged 33-44 years). They performed a high impact training programme (lower limbs group) or high impact and resistance training in the upper limbs (upper + lower group) for 12 months, which resulted in an increased greater trochanter BMD in both groups and lumbar spine BMD only in the upper + lower group.

An 18-month high impact training programme (jumps + calisthenics) without concurrent strength training has been reported to increase femoral neck BMD by $1.6 \%$ in women aged $35-45$ years. ${ }^{[126]}$

In combination, these results indicate that targeted training could be effective in women with low bone mass in an isolated bone site - a potentially inexpensive and safe way to prevent and/or treat osteoporosis later in life. In a mixed population (21 men and 35 women aged 19-38 years), whole-body vibration - administered during 8 months $(4 \mathrm{~min} /$ day, three to five times per week) at $25-45 \mathrm{~Hz}$, corresponding to estimated maximum vertical accelerations of $2-8 g-$ had no effect on mass, structure or estimated strength of bone at any skeletal site. ${ }^{[141]}$ Serum markers of bone turnover did not change during the vibration intervention. ${ }^{[141]}$ These findings contrast with those of Beck et al., ${ }^{[142]}$ who reported a $2 \%$ increase in $\mathrm{BMD}$ in the proximal femur of five premenopausal women (age 18-45 years) submitted to whole-body vibration $(30 \mathrm{~Hz} ; 2 \times 10 \mathrm{~min} /$ day; $0.2 \mathrm{~g}$ stimulus) for 12 months. This study, however, must be interpreted cautiously because it lacked a control group and one of the women was on treatment with biphosphonates. ${ }^{[142]}$ Thus, it remains to be determined whether whole-body vibration alone or in combination with strength training could be an efficient stimulus to enhance BMD in 
premenopausal women with either normal or reduced BMD at the start of the programme.

\subsubsection{Middle-Aged Men}

The effects of exercise on bone mass and structure in middle-aged men are controversial. Strength training (three times per week at 5-15 $\mathrm{RM}$ ) in men aged 54-61 years for 4 months resulted in a $2.0 \%$ gain in lumbar spine and $3.8 \%$ gain in femoral neck BMD after this period. ${ }^{[143]}$ On the other hand, regular aerobic (40-60\% $\dot{\mathrm{V}} \mathrm{O}_{2 \max }$ ) exercise in men (age 53-62 years) for a long time (48 months) does not appear to have beneficial effects on the age-related loss of femoral BMD, suggesting that starting regular aerobic exercise in middle age to prevent osteoporosis in men may not be efficacious. ${ }^{[144]}$ However, when aerobic exercise was combined with strength training for 6 months, WBBMD was maintained..$^{[145]}$

A unique study that involved both sexes in the same exercise programme showed that 6 months of moderate strength training (50\% $1 \mathrm{RM})$ and moderate aerobic training (60-90\% maximal heart rate) maintained WBBMD in males but decreased WBBMD in females. ${ }^{[145]}$ Both males and females experienced exercise-induced bodyweight and fat losses, suggesting that although lean mass was increased after the training period (3\%), the negative effect of losing weight on BMD was stronger, although the age range of the participants was too great (55-75 years) ${ }^{[145]}$ Nevertheless, a lack of randomized controlled trials testing any kind of training and bone measurements in middle-aged men precludes any definitive conclusion on the effects of exercise on bone mass in this segment of the population. ${ }^{[146]}$

\subsection{Aging}

Some authors support the hypothesis that the magnitude of the peak skeletal mass in the first three decades of life probably accounts for the variability in bone mass in elderly persons, ${ }^{[147]}$ but it is currently impossible to prove or disprove this theory because there are no studies with randomized controlled trials from puberty to old age that have investigated bone fractures as an endpoint. These studies would require extremely large cohorts and a $>50$-year study duration before the research question could be answered. Furthermore, traits independent of BMD, such as skeletal architecture, bone size, balance, muscle strength and neuromuscular propioception, may also be affected by exercise, all of which could influence the fracture risk, and are not reviewed in this article. ${ }^{[148,149]}$

The Leisure World Study reported that women with an activity level $>1$ hour a day had a reduced risk of hip fracture, but the beneficial effect was lost if the activity level was reduced. ${ }^{[150]}$ In the Study of Osteoporotic Fracture, a longitudinal study including 9704 women $>65$ years of age and followed for about 8 years, women in the highest quintile of current activity level had a $42 \%$ lower hip fracture risk than the least active quintile of women, and self-reported walking time was associated with a $30 \%$ reduction in hip fracture risk during a 4.1-year follow-up. ${ }^{[43]}$

Studies evaluating the question of whether bone mass is maintained after a reduction or cessation of exercise show contrasting results, irrespective of the level of BMD found in retired athletes. To evaluate the hypothesis that exercise during growth reduces the clinical problem of fragility fractures, it would be needed to demonstrate that retired athletes have fewer fractures than controls. Wyshak et al. ${ }^{[151]}$ compared a large cohort $(n=10796)$ of former female college athletes with sedentary controls aged 21-80 years. The number of former athletes with fractures after retirement was no different than among the controls. Among women aged $\geq 60$ years, who were fracture-free up to the age of 40 years, the rate of any fracture at age $\geq 40$ years was $29 \%$ for former athletes compared with $32 \%$ for non-athletes, a nonsignificant difference. Nordström et al. ${ }^{[41]}$ measured BMD in two cohorts; the first comprised 65 young male ice hockey players, 73 young soccer players (two high-impact sports) and 61 age-matched controls. Measures were taken again after 5 years; at that time, 55 athletes had retired from their active sports career. The second cohort comprised 400 former soccer and ice hockey players and 800 age- and sex-matched controls. At baseline, 
all active groups had higher BMD values at whole body, femoral neck, lumbar spine and arms compared with controls; after 5 years the young retired athletes still had a 4-8\% higher BMD than controls, whereas young athletes increased the difference in BMD compared with the controls at femoral neck and arms. These results suggest that higher BMD persists until several decades after retirement. Furthermore, retired athletes had fewer fractures than controls. Therefore, it seems that exercise during childhood and adolescence may be associated with lower risk of sustaining fragility fractures during old age in men, ${ }^{\left[{ }^{[9]}\right.}$ but in women these beneficial results only persist if exercise practice is maintained.

The effects of exercise protocols on bone density have also been reported in older populations; a review of recent longitudinal studies is provided in tables IV and V for women and men, respectively.

\subsection{Postmenopausal Women}

Nelson et a1. ${ }^{[152]}$ completed a 1-year randomized, controlled trial of high-intensity resistance training in postmenopausal women. The results of the study demonstrated that women in a 2 days/ week resistance training programme gained an average of $1 \%$ in BMD of the femoral neck and lumbar spine whereas the control group lost $2.5 \%$ and $1.8 \%$ at these sites, respectively. In addition, the resistance-trained women tended to maintain WBBMC of the skeleton whereas the women in the control group had a $1.2 \%$ decline in WBBMC. Also, the resistance-trained women had $35-76 \%$ increase in strength, $14 \%$ improvement in dynamic balance, and a $1.2 \mathrm{~kg}$ increase in total body lean mass and a $27 \%$ increase in physical activity unrelated to the intervention, whereas the control group showed declines in all of these parameters. In agreement with these results, Kerr et al. ${ }^{[153]}$ reported that postmenopausal bone mass can be significantly increased by a strength regimen that uses high loads and a low number of repetitions $(3 \times 8 \mathrm{RM})$ but not by an endurance regimen that uses low loads and a high number of repetitions $(3 \times 20 \mathrm{RM})$. In 1-7 years, postmenopausal women, following
9 months of strength training with intermediate loads $(2 \times 10-15 \mathrm{RM})$, lumbar spine BMD was enhanced by $1.6 \%$. In this study, each subject performed one set of 10-12 RM (increasing progressively) for upper body training and one set of 10-15 RM for lower body training. In contrast, the women from the control group experienced a $3.6 \%$ decline in lumbar spine BMD. ${ }^{[159]}$ Altogether, these studies show that the peak load is more important than the number of loading cycles in increasing bone mass in postmenopausal women.

In late postmenopausal women (aged 60-72 years), 9 months of endurance training (mostly running at $60-70 \%$ of $\dot{\mathrm{V}} \mathrm{O}_{2 \max }$, three to four times a week, for $35-50 \mathrm{~min} / \mathrm{session}$ ) either alone or in combination with hormone replacement therapy (HRT) resulted in significant increases in lumbar spine and femoral neck. ${ }^{[154]}$ Exercise and HRT resulted in independent and additive effects on the BMD of the lumbar spine and Ward's triangle, and a synergistic effect on whole body BMD. These effects were accompanied by a reduction in serum osteocalcin levels, indicating that increases in BMD in response to HRT and to exercise + HRT were due to decreased bone turnover. ${ }^{[154]}$ The lack of change in serum osteocalcin and IGF-I in response to exercise alone suggests that the increases in BMD were due to decreased bone resorption and not to increased formation. ${ }^{[154]}$

Other studies have reported just the maintenance of BMD in postmenopausal women with resistance training. ${ }^{[155,162]}$ There is evidence that postmenopausal women respond differently to a resistance training programme than do premenopausal women. ${ }^{[163,164]}$ Bassey et al. ${ }^{[163]}$ studied the effects of a vertical jumping exercise regimen on BMD using randomized controlled trials in both pre- and postmenopausal women, the latter stratified for HRT. The exercise consisted of 50 vertical jumps on 6 days/week of mean height $8.5 \mathrm{~cm}$, which produced mean ground reactions of 3.0 times bodyweight in the young women and 4.0 times in the older women. In the premenopausal women, the exercise resulted in a significant increase of $2.8 \%$ in femoral BMD after 5 months. In the postmenopausal women, there 
Table IV. Effects of training protocols on bone tissue adaptations in young men, middle-aged men and age-specific sex comparisons: longitudinal studies

\begin{tabular}{|c|c|c|c|c|c|c|c|c|c|c|c|}
\hline \multirow[t]{2}{*}{ Study } & \multicolumn{3}{|l|}{ Subjects } & \multirow[t]{2}{*}{ Training } & \multirow[t]{2}{*}{ Frequency } & \multirow[t]{2}{*}{ Exercises } & \multirow{2}{*}{$\begin{array}{l}\text { Protocol } \\
\text { time } \\
(\mathrm{mo})\end{array}$} & \multirow{2}{*}{$\begin{array}{l}\text { Training } \\
\text { intensity }\end{array}$} & \multirow[t]{2}{*}{ Other } & \multirow{2}{*}{$\begin{array}{l}\text { Bone } \\
\text { measurement } \\
\text { site (s) }\end{array}$} & \multirow[t]{2}{*}{ Results } \\
\hline & $\mathrm{n}$ & $\mathrm{M} / \mathrm{F}$ & age $(y)$ & & & & & & & & \\
\hline \multicolumn{12}{|l|}{ Young men } \\
\hline $\begin{array}{l}\text { Hartman et al. }{ }^{[137]} \\
(2007)\end{array}$ & $\begin{array}{l}E X M=18 \\
E X S=19 \\
C=19\end{array}$ & $M$ & $18-30$ & RT & $\begin{array}{l}5 / \text { wk } \\
2-4 \\
\text { sets } \times 4-12 \\
\text { rep }\end{array}$ & $\begin{array}{l}\text { Military press, bench } \\
\text { press, seated chest fly, } \\
\text { seated triceps } \\
\text { extension, seated } \\
\text { lateral pull down, } \\
\text { seated wide grip row, } \\
\text { seated reverse fly, } \\
\text { seated biceps curl, } \\
\text { abdominals, inclined } \\
\text { leg press, 2-leg knee } \\
\text { extension, 2-leg } \\
\text { hamstring curl, seated } \\
\text { calf raise }\end{array}$ & 3 & $\begin{array}{l}80 \% \\
1 \mathrm{RM}\end{array}$ & $\begin{array}{l}500 \mathrm{~mL} \\
\mathrm{M} / \mathrm{S} \text { in } \\
\mathrm{EXM} ; \\
500 \mathrm{~mL} \\
\mathrm{~S} / \mathrm{S} \text { in } \\
\mathrm{EXS} ; \\
500 \mathrm{~mL} \\
\mathrm{C} / \mathrm{S} \text { in } \\
C\end{array}$ & WB & $\mathrm{NC}$ \\
\hline $\begin{array}{l}\text { Ballard et al. }{ }^{[138]} \\
(2006)\end{array}$ & $\begin{array}{l}\text { YMEX }=13 \\
Y W E X=12 \\
C M=12 \\
C W=11\end{array}$ & $M / F$ & $20-22$ & $\mathrm{RT}+\mathrm{ET}$ & $\begin{array}{l}5 / \text { wk } \\
3 \text { sets } \times 12- \\
\text { failure rep }\end{array}$ & $\begin{array}{l}\text { Bench press, inclined } \\
\text { bench press, shoulder } \\
\text { press, lat pulldown; } \\
\text { cable rows, arm curl } \\
\text { and extensions, hip } \\
\text { sled, squats, calf } \\
\text { raises + aerobics }\end{array}$ & 6 & $\begin{array}{l}70 \% \\
1 \mathrm{RM} ; \\
70 \% \\
\dot{\mathrm{V}}_{2 \max }\end{array}$ & $\begin{array}{l}\text { EX: } \\
42 \mathrm{~g} \\
\mathrm{P} / \mathrm{S} \\
\mathrm{C}: 70 \mathrm{~g} \\
\mathrm{C} / \mathrm{S}\end{array}$ & $\mathrm{T}, \mathrm{WB}, \mathrm{A}, \mathrm{L}$ & $\begin{array}{l}\uparrow T \text { VBMD } \\
\text { in YMEX } \\
\text { and YWEX } \\
\uparrow A B M C \text { in } \\
\text { YMEX and } \\
\text { YWEX }\end{array}$ \\
\hline $\begin{array}{l}\text { Ryan et al..[139] } \\
\text { (2004) }\end{array}$ & $\begin{array}{l}\text { YWEX }=8 \\
O W E X=11 \\
Y M E X=13 \\
O M E X=10\end{array}$ & $M / F$ & $\begin{array}{l}Y=20-29 \\
O=65-74\end{array}$ & RT & $\begin{array}{l}3 / \text { wk } 2 \text { sets, } \\
\text { failure }\end{array}$ & $\begin{array}{l}\text { Leg press, chest press, } \\
\text { leg curl, lat pulldown; } \\
\text { leg extension, military } \\
\text { press, seated row, } \\
\text { triceps pulldown, } \\
\text { abdominal crunch, } \\
\text { biceps curl, sit ups }\end{array}$ & 6 & $\begin{array}{l}12-15 \\
\mathrm{RM}\end{array}$ & & $\begin{array}{l}\text { WB, SP, FN, } \\
\text { WT, GT }\end{array}$ & $\begin{array}{l}\uparrow \text { FNBMD } \\
\text { in ESP }\end{array}$ \\
\hline $\begin{array}{l}\text { Fujimura et al. }{ }^{[136]} \\
\text { (1997) }\end{array}$ & $\begin{array}{l}\mathrm{EX}=8 \\
\mathrm{C}=7\end{array}$ & $M$ & $23-31$ & $\mathrm{RT}$ & $\begin{array}{l}3 / \text { wk } \\
2-3 \\
\text { sets } \times 10 \\
\text { rep }\end{array}$ & $\begin{array}{l}\text { Leg extension, leg curl, } \\
\text { bench press, sit up, } \\
\text { back extension, arm } \\
\text { curl, wrist curl, half } \\
\text { squat leg lunge, lateral } \\
\text { pull down, back press }\end{array}$ & 4 & $\begin{array}{l}60-80 \% \\
1 \mathrm{RM}\end{array}$ & & $\begin{array}{l}\text { WB, FN, } \\
\text { SP, R }\end{array}$ & $\mathrm{NC}$ \\
\hline
\end{tabular}




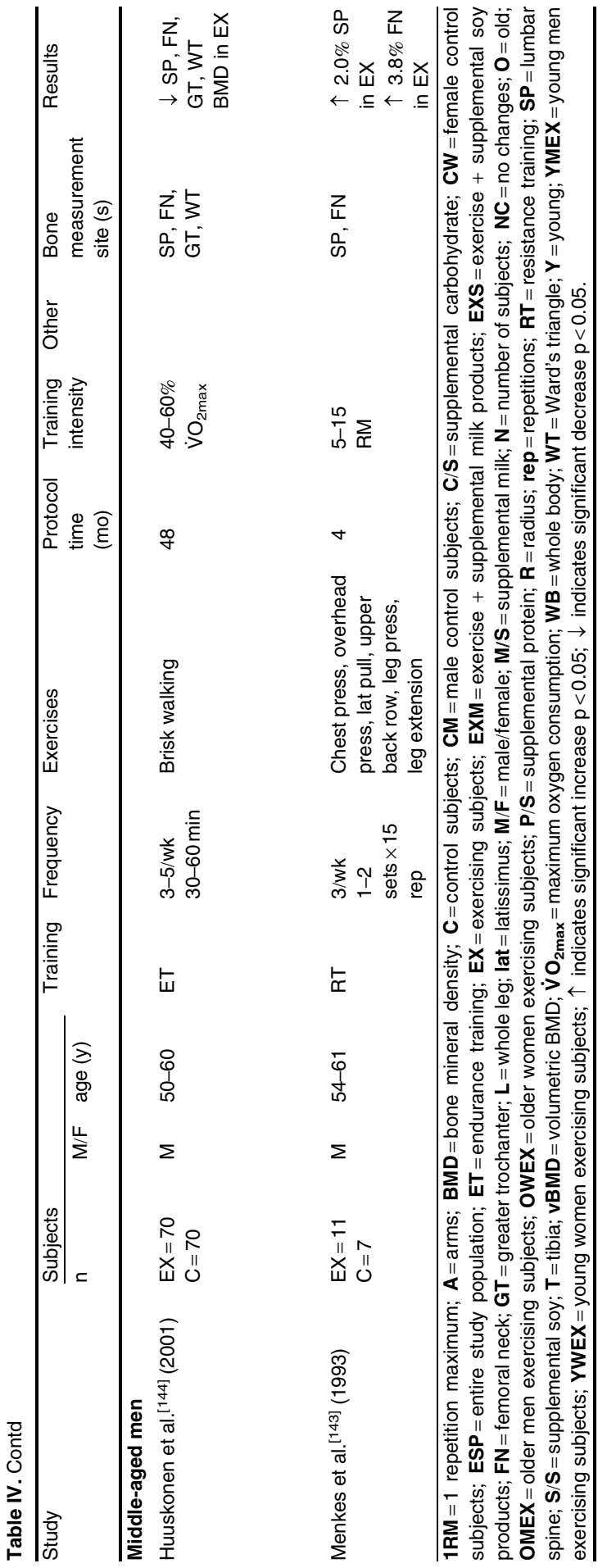

was no significant difference between the exercise and control groups after 12 months (total $\mathrm{n}=123$ ) nor after 18 months (total $\mathrm{n}=38$ ). HRT status did not affect this outcome, at least up to 12 months. Sugiyama et al. ${ }^{[64]}$ studied a group of Japanese female volunteers aged around 50 years divided into premenopausal women with a regular menstruation cycle and postmenopausal women within 5 years since menopause. About half of the subjects in each group chose to be non-exercisers. The remainder followed a 6 -month training programme consisting of rope skipping (100 jumps/day, with an interval of 2-3 days). In total, they completed 10 days per month, 60 days during the study period. Among the premenopausal women, the BMD in the exercise group increased significantly compared with the controls for total hip $(+1.6 \%)$ and femoral neck $(2.4 \%)$, but changes at the whole body and lumbar spine levels were not significant. In contrast, there were no significant differences at any measurement sites among the postmenopausal women. Interestingly, in the premenopausal exercise group, the baseline value of urinary $\gamma$-carboxyglutamate (Gla) residues (an indirect measure of osteocalcin carboxylation) was inversely correlated $(\mathrm{r}=-0.62)$ with the change in whole body BMD. The latter could indicate that bone gain induced by high impact exercise could become greater in proportion to the degree of deterioration in bone material properties. ${ }^{[164]}$

Therefore, although optimum training strategies are still under discussion, it is generally acknowledged that the training should be population specific. Stengel et al. ${ }^{[155]}$ tested the hypothesis that power training was more effective than conventional strength training for maintaining BMD at lumbar spine and hip. Forty-two postmenopausal women performed a 12-month training programme; the only difference between the two groups was the velocity at which movements were performed. The training protocol specified a 4-second concentric, 4-second eccentric sequence in the resistance training group, and a concentric fast/explosive 4-second eccentric sequence in the power training group. In addition, all women performed gymnastics and home training sessions. Women involved 
Table V. Effects of training protocols on bone tissue adaptations in older women, men and age-specific sex comparisons: Iongitudinal studies

\begin{tabular}{|c|c|c|c|c|c|c|c|c|c|c|c|}
\hline \multirow[t]{2}{*}{ Study } & \multicolumn{3}{|l|}{ Subjects } & \multirow[t]{2}{*}{ Training } & \multirow[t]{2}{*}{ Frequency } & \multirow[t]{2}{*}{ Exercises } & \multirow{2}{*}{$\begin{array}{l}\text { Protocol } \\
\text { time } \\
(\mathrm{mo})\end{array}$} & \multirow{2}{*}{$\begin{array}{l}\text { Training } \\
\text { intensity }\end{array}$} & \multirow[t]{2}{*}{ Other } & \multirow{2}{*}{$\begin{array}{l}\text { Bone } \\
\text { measurement } \\
\text { site (s) }\end{array}$} & \multirow[t]{2}{*}{ Results } \\
\hline & $n$ & $\mathrm{M} / \mathrm{F}$ & $\begin{array}{l}\text { age } \\
\text { (y) }\end{array}$ & & & & & & & & \\
\hline \multicolumn{12}{|l|}{ Older women } \\
\hline $\begin{array}{l}\text { Nelson et al.. }{ }^{[152]} \\
\text { (1994) }\end{array}$ & $\begin{array}{l}E X=20 \\
C=19\end{array}$ & $\mathrm{~F}$ & $50-70$ & RT & $\begin{array}{l}2 / \text { wk } \\
3 \text { set } \times 8 \text { rep }\end{array}$ & 5 weight-lifting exercises & 12 & $\begin{array}{l}80 \% \\
1 \mathrm{RM}\end{array}$ & & WB, SP, FN & $\begin{array}{l}\uparrow 1 \% \text { SPBMD in EX } \\
\uparrow 1 \% \text { FNBMD in EX } \\
\downarrow 1.8 \% \text { SPBMD in C } \\
\downarrow 2.5 \% \text { FNBMD in C }\end{array}$ \\
\hline $\begin{array}{l}\text { Kerr et al. }{ }^{[153]} \\
(1996)\end{array}$ & $\begin{array}{l}\text { REX } \\
\text { EEX } \\
C\end{array}$ & & & $\begin{array}{l}\text { RT } \\
\text { ET }\end{array}$ & & & 12 & & & & \\
\hline $\begin{array}{l}\text { Kohrt et al. }{ }^{[154]} \\
\text { (1995) }\end{array}$ & $\begin{array}{l}\text { REX } \\
C\end{array}$ & $\mathrm{~F}$ & & RT & $3 / w k$ & Weight-bearing exercises & 12 & & HRTh & & \\
\hline $\begin{array}{l}\text { Stengel et al. }{ }^{[155]} \\
(2005)\end{array}$ & $\begin{array}{l}P E X=21 \\
R E X=21\end{array}$ & $\mathrm{~F}$ & $54-60$ & $\begin{array}{l}\text { PT } \\
\text { RT }\end{array}$ & $4 / w k$ & $\begin{array}{l}2 \text { weight-lifting sessions } \\
1 \text { gymnastics session } \\
1 \text { home training session }\end{array}$ & 12 & $\begin{array}{l}\text { 70-90\% } \\
1 \mathrm{RM}\end{array}$ & $\begin{array}{l}1.500 \mathrm{mg} \\
\mathrm{Ca} / \mathrm{S}, 500 \\
\text { Vit-D/S }\end{array}$ & $\begin{array}{l}\text { SP, WH, } \\
\text { FN, T, IT }\end{array}$ & $\begin{array}{l}\text { NC FNBMD in PEX } \\
\text { NC SPBMD in PEX } \\
\downarrow 0.9 \% \text { SPBMD } \\
\text { in REX } \\
\downarrow 1.2 \% \text { WHBMD } \\
\text { in REX }\end{array}$ \\
\hline $\begin{array}{l}\text { Chien et al. }{ }^{[156]} \\
(2000)\end{array}$ & $\begin{array}{l}E X=22 \\
C=21\end{array}$ & $\mathrm{~F}$ & $48-65$ & $\mathrm{ET}+\mathrm{HIT}$ & $\begin{array}{l}3 / \mathrm{wk} \\
50 \mathrm{~min}\end{array}$ & $\begin{array}{l}\text { Treadmill walking + stepping } \\
\text { exercise }\end{array}$ & 6 & $\begin{array}{l}70-85 \% \\
\dot{V O O}_{2 \max }\end{array}$ & $\begin{array}{l}\text { Osteopenic } \\
\text { subjects } \\
\text { HRTh }\end{array}$ & WB, SP, FN & $\begin{array}{l}\uparrow 6.8 \% \text { FNBMD } \\
\text { in } \mathrm{EX}\end{array}$ \\
\hline $\begin{array}{l}\text { Kohrt et al. }{ }^{[157]} \\
\text { (1997) }\end{array}$ & $\begin{array}{l}\text { GREX } \\
\text { JREX } \\
\text { C }\end{array}$ & $\mathrm{F}$ & $60-74$ & $\begin{array}{l}E T \\
R T+E T\end{array}$ & $\begin{array}{l}3 / \text { wk } \\
\text { GREX: } \\
30-45 \text { min } \\
\text { JREX: } \\
2-3 \\
\text { sets } \times 8-12 \\
\text { rep } \\
15-20 \text { min }\end{array}$ & $\begin{array}{l}\text { GREX: walking, jogging, } \\
\text { stair climbing } \\
\text { JREX: overhead press, } \\
\text { biceps curl; } \\
\text { triceps extension, leg press, } \\
\text { leg extension, leg flexion, } \\
\text { bench press, squats }\end{array}$ & 11 & $\begin{array}{l}\text { GREX: } \\
60-85 \\
\text { MHR } \\
\text { JREX: } \\
8-12 \\
\text { RM, } \\
60-85 \\
\text { MHR }\end{array}$ & & $\begin{array}{l}\text { WB, SP, FN, } \\
\text { GT, W }\end{array}$ & $\begin{array}{l}\uparrow 2.0 \% \text { WBBMD } \\
\text { in GREX } \\
\uparrow 1.6 \% \text { WBBMD } \\
\text { in JREX } \\
\uparrow 1.8 \% \text { SPBMD } \\
\text { in GREX } \\
\uparrow 1.5 \% \text { SPBMD } \\
\text { in JREX } \\
\uparrow 6.1 \% \text { GTBMD } \\
\text { in GREX } \\
\uparrow 5.1 \% \text { GTBMD } \\
\text { in GREX }\end{array}$ \\
\hline $\begin{array}{l}\text { Verschueren } \\
\text { et al. }{ }^{[158]}(2004)\end{array}$ & $\begin{array}{l}\text { VEX: } 25 \\
\text { EX: } 22 \\
\text { C: } 23\end{array}$ & $\mathrm{~F}$ & $60-70$ & $\begin{array}{l}\text { VEX: } \\
\text { RT + WBV } \\
\text { EX: RT }\end{array}$ & $\begin{array}{l}\text { VEX, EX: } \\
3 / \text { wk } \\
1-3 \\
\text { sets } \times 10-15\end{array}$ & $\begin{array}{l}\text { VEX and EX: } \\
\text { leg extension, } \\
\text { leg press }\end{array}$ & 6 & $\begin{array}{l}\text { VEX, } \\
\text { EX: } \\
20-8 \\
\text { RM }\end{array}$ & & WB, F, SP & $\begin{array}{l}\uparrow 0.9 \% \text { FBMD in } \\
\text { VEX } \\
\text { NC in EX and } C\end{array}$ \\
\hline
\end{tabular}




\begin{tabular}{|c|c|c|c|c|c|c|c|c|c|c|c|}
\hline \multirow[t]{2}{*}{ Study } & \multicolumn{3}{|l|}{ Subjects } & \multirow[t]{2}{*}{ Training } & \multirow[t]{2}{*}{ Frequency } & \multirow[t]{2}{*}{ Exercises } & \multirow{2}{*}{$\begin{array}{l}\text { Protocol } \\
\text { time } \\
(\mathrm{mo})\end{array}$} & \multirow{2}{*}{$\begin{array}{l}\text { Training } \\
\text { intensity }\end{array}$} & \multirow[t]{2}{*}{ Other } & \multirow{2}{*}{$\begin{array}{l}\text { Bone } \\
\text { measurement } \\
\text { site (s) }\end{array}$} & \multirow[t]{2}{*}{ Results } \\
\hline & $\bar{n}$ & $\mathrm{M} / \mathrm{F}$ & $\begin{array}{l}\text { age } \\
(y)\end{array}$ & & & & & & & & \\
\hline $\begin{array}{l}\text { Pruitt et al..[159] } \\
\text { (1992) }\end{array}$ & $\begin{array}{l}\text { EX: } 17 \\
C: 10\end{array}$ & $\mathrm{~F}$ & $52-56$ & RT & $\begin{array}{l}3 / \text { wk } \\
1 \text { set } \times 10-15 \\
\text { rep }\end{array}$ & $\begin{array}{l}\text { Biceps curl, lat } \\
\text { pulldown, bench press, } \\
\text { wrist roller, leg press, } \\
\text { leg ab/adduction, } \\
\text { leg curl, leg extension, trunk } \\
\text { extension, hip extension, } \\
\text { lateral flexion }\end{array}$ & 9 & $\begin{array}{l}10-15 \\
\mathrm{RM}\end{array}$ & & SP, FN & $\begin{array}{l}\uparrow 1.6 \% \text { SPBMD } i \\
\text { EX } \\
\downarrow 3.6 \% \text { SPBMD i } \\
C\end{array}$ \\
\hline \multicolumn{12}{|l|}{ Older men } \\
\hline $\begin{array}{l}\text { Maddalozzo } \\
\text { et al. }{ }^{[160]}(2000)\end{array}$ & $\begin{array}{l}\operatorname{MMEX}=12 \\
\mathrm{HMEX}=12 \\
\mathrm{MWEX}=9 \\
\mathrm{HWEX}=9\end{array}$ & $\mathrm{M} / \mathrm{F}$ & $50-60$ & $\begin{array}{l}\text { MRT } \\
\text { HRT }\end{array}$ & $\begin{array}{l}\text { MRT: } 3 / \text { wk } \\
3 \text { sets } \times \\
10-13 \text { rep } \\
\text { HRT: } 3 / \text { wk } \\
3 \text { sets } \times 2-10 \\
\text { rep }\end{array}$ & $\begin{array}{l}\text { M: Leg press, leg extension } \\
\text { hamstring curls, arm curl, } \\
\text { triceps press, chest press, } \\
\text { Pec deck, shoulder press, } \\
\text { side lateral raise, lat pulldown, } \\
\text { seated row, abdominal } \\
\text { crunch, calf raise } \\
\text { H: free weight back squat, } \\
\text { deadlift, biceps curls, sit ups, } \\
\text { triceps extension, chest } \\
\text { press, incline shoulder press, } \\
\text { high lat pull down, leg curl, } \\
\text { gripper, calf raise. }\end{array}$ & 6 & $\begin{array}{l}\text { MRT: } \\
40-60 \% \\
\text { 1 RM } \\
\text { HRT: } \\
\text { 70-90\% } \\
\text { 1 RM }\end{array}$ & & $\begin{array}{l}\text { WH, FN, } \\
\text { GT, SP }\end{array}$ & $\begin{array}{l}\uparrow 1.9 \% \text { SPBMD } \\
\text { HMEX } \\
\uparrow 1.3 \% \text { GTBMD } \\
\text { HMEX } \\
\uparrow 2.0 \% \text { GTBMD } \\
\text { HWEX }\end{array}$ \\
\hline $\begin{array}{l}\text { Ryan et al..[161] } \\
\text { (1994) }\end{array}$ & $\begin{array}{l}E X=21 \\
C=16\end{array}$ & $M$ & $51-71$ & RT & $\begin{array}{l}3 / \text { wk } \\
2 \text { sets } \times 15 \\
\text { rep }\end{array}$ & $\begin{array}{l}\text { Leg press, } \\
\text { chest press, leg curl, } \\
\text { lat pull down, leg extension, } \\
\text { military press, adductor, } \\
\text { abductor, upper back, triceps, } \\
\text { lower back, abdominals, } \\
\text { biceps curl }\end{array}$ & 4 & $5 \mathrm{RM}$ & $\begin{array}{l}\text { Dietary } \\
\text { control }\end{array}$ & WB, SP, FN & $\begin{array}{l}\uparrow 2.8 \% \text { FNBMD } \\
\text { EX }\end{array}$ \\
\hline $\begin{array}{l}\text { Stewart et al.. }{ }^{[45]} \\
(2005)\end{array}$ & $\begin{array}{l}\text { MRT }=26 \\
\text { WRT }=31 \\
C=58\end{array}$ & $\mathrm{M} / \mathrm{F}$ & $55-75$ & $\mathrm{RT}+\mathrm{ET}$ & $\begin{array}{l}3 / \text { wk } \\
2 \text { sets } \times 10-15 \\
\text { rep }\end{array}$ & $\begin{array}{l}\text { Bench press, shoulder press, } \\
\text { seated mid-rowing, lat } \\
\text { pulldown, leg extension, } \\
\text { leg curl, leg press }\end{array}$ & 6 & & $\begin{array}{l}\text { Hypertensive } \\
\text { subjects }\end{array}$ & $\begin{array}{l}\text { WB, SP, FN, } \\
\text { IT, WH }\end{array}$ & $\begin{array}{l}\uparrow 1.7 \% \text { SPBMD } \\
\text { MRT }\end{array}$ \\
\hline
\end{tabular}

$\mathbf{1 R M}=1$ repetition maximum; $\mathbf{C a} / \mathbf{S}=$ supplemental calcium; $\mathbf{E E X}=$ endurance training exercising subjects; $\mathbf{E T}=$ endurance training; $\mathbf{E X}=$ exercising subjects; $\mathbf{F}=$ femur; $\mathbf{F N}=$ femoral neck; GREX = ground reaction forces exercising subjects; $\mathbf{G T}=$ greater trochanter; $\mathbf{H}=$ high-intensity exercises; $\mathbf{H I T}=$ high-impact training; $\mathbf{H M E X}=$ men high-intensity exercising subjects; HRT=high-intensity resistance training; HRTh=hormone replacement therapy; HWEX=women high-intensity exercising subjects; IT=intertrochanteric subregion; JREX = joint reaction forces exercising subjects; lat = latissimus; $\mathbf{M}=$ moderate-intensity exercises; $\mathbf{M} / \mathbf{F}=$ male/female; $\mathbf{M H R}=$ maximal heart rate; $\mathbf{M M E X}=$ men moderate-intensity exercising subjects; $\mathbf{M R T}=$ moderate resistance training; $\mathbf{M W E X}=$ women moderate-intensity exercising subjects; $\mathbf{N}=$ number of subjects; $\mathbf{N C}=$ no changes; $\mathbf{p e c}=$ pectoralis; $\mathbf{P E X}=$ power exercising subjects; $\mathbf{P T}=$ power training; $\mathbf{r e p}=$ repetition; $\mathbf{R E X}=$ resistance training exercising subjects; $\mathbf{R T}=$ resistance training; $\mathbf{S P}=$ lumbar spine; $\mathbf{T}=$ tibia; VEX = vibratory exercising subjects; Vit-D/S= supplemental vitamin $\mathrm{D} ; \dot{\mathbf{V}} \mathbf{O}_{\mathbf{2 m a x}}=$ maximum oxygen consumption; $\mathbf{W}=$ wrist; $\mathbf{W B}=$ whole body; $\mathbf{W B V}=$ whole body vibration; $\underline{\mathbf{W H}}=$ whole hip; $\uparrow$ indicates significant increase $\mathrm{p}<0.05 ; \downarrow$ indicates significant decrease $\mathrm{p}<0.05$. 
in the power training group maintained their BMD at lumbar spine and hip, whereas resistance training women experienced a significant decrease in lumbar spine and hip sites from baseline. These results indicate that to elicit a osteogenic response in older women, the strains and ground reaction forces required may be higher than those able to elicit a similar or even greater response in younger women.

Palombaro ${ }^{[165]}$ reviewed the effects of walkingonly programmes on BMD at various skeletal sites. This meta-analysis showed that walking interventions alone did not attenuate bone loss at the skeletal sites reported. Thus, other forms of exercise in addition to walking should be incorporated into training regimens for patients at risk for osteoporosis. Supporting this notion, Chien et al. ${ }^{[156]}$ examined the efficacy of a 24-week aerobic plus high exercise programme for osteopenic postmenopausal women, and this appeared to be effective in offsetting the age-related decline of BMD, especially at the femoral neck, which showed a significant improvement of $6.8 \%$ in the exercise group.

Kohrt et al. ${ }^{[157]}$ applied two different training protocols to postmenopausal women at risk of osteoporosis. The first protocol consisted of exercises that stimulated the skeleton through ground-reaction forces (walking, jogging, stair climbing), while the second protocol included activities eliciting joint-reaction forces (weightlifting, rowing). The intensity was initially set at a low level (60\% maximal heart rate, $12 \mathrm{RM})$ and progressed with training (to $85 \%$ maximal heart rate, $8 \mathrm{RM}$ ). After 11 months, BMD was increased at the whole body level and femoral neck in both groups, but the effects were greater in the ground reaction than the joint-reaction group. ${ }^{[157]}$ These results could be explained by the combination of walking, jogging and stair climbing, which may generate ground reaction forces between $2.8-6$ times bodyweight ${ }^{[166]}$ in the ground reaction group, and the use of free weights in the resistance training combined with rowing in the joint reaction group. However, more randomized, controlled studies testing aerobic plus high-impact training in older adults are needed.
Whole body vibration training in postmenopausal women has been shown to increase femoral neck BMD and balance more than walking. ${ }^{[167]}$ Compared with resistance exercises progressing from low (20 RM) to high (8 RM) loading conditions, 6 months of static and dynamic knee extensor exercises on a vibration platform $(35-40 \mathrm{~Hz} ; 2.28-5.09 \mathrm{~g})$ enhanced hip BMD by $0.9 \% . .^{[158]}$ In another study, whole body vibration inhibited bone loss in the spine and femur of postmenopausal women. ${ }^{[168]}$ These authors performed a 1-year prospective, randomized, double-blind, placebo-controlled trial of 70 postmenopausal women who undertook brief periods ( $<20$ minutes) of a low-level $(30 \mathrm{~Hz} ; 0.2 \mathrm{~g})$ vibration applied during quiet standing. The efficacy of this intervention was enhanced in the women with significantly greater compliance, particularly in those subjects with lower body mass. ${ }^{[168]}$

The studies in postmenopausal women indicate that BMD can be increased, or at least the decline in bone mass during the menopause attenuated, following weight training exercises. The osteogenic effects are site specific and can only be achieved with high loading intensities $(>70 \%$ of $1 \mathrm{RM}$ ) with 3-4 sessions per week and 2-3 sets per session. ${ }^{[169]}$ Although significant effects can be observed after 4-6 months in some locations, the efficacy of the training programme is greater when extended for $\geq 1$ year. Combining strength training with aerobic exercise may also result in positive effects on BMD. Whole body vibration alone or in combination with exercise may help to increase or at least prevent BMD decline with aging in postmenopausal women. However, the gains in bone density and neuromuscular functions achieved by training are lost 5 years after cessation of training. ${ }^{[170]}$ Continuous highintensity weight-loading physical activity is probably necessary to preserve bone density and neuromuscular function in older women.

\subsection{Older Men}

Older men have been much less studied than older women, possibly because of the lower osteoporotic fracture incidence in men. ${ }^{[171]}$ One of 
these studies compared the effects of either a moderate (three sets of $10-13$ repetitions at $40-60 \%$ of $1 \mathrm{RM}$ ) or high (three sets of $2-10$ repetitions at $70-90 \%$ of $1 \mathrm{RM}$ ) intensity resistance training programme (with exercises involving all major muscle groups) in men and women aged 50-60 years. ${ }^{[160]}$ Both older men and older women achieved significant increases in muscular strength and muscle mass regardless of intensity or training protocol. ${ }^{[160]}$ The high-intensity training men experienced a significant increase in lumbar spine and greater trochanter BMD; however, women training with high-intensity increased greater trochanter BMD only slightly, maybe because these women were primarily early postmenopausal (within 36 months), a time during which there is accelerated bone loss of 2-6.5\% per year. High-intensity free weight training was tolerated well by older adults and produced BMD changes in only 6 months. In older men, high-intensity training was more osteogenic at the lumbar spine than moderateintensity training. In agreement with Maddalozzo and Snow ${ }^{[160]}$ Stewart et al. ${ }^{[145]}$ reported no effect on BMD in men (55-75 years old) following 6 months of multistation machine at $50 \%$ of $1 \mathrm{RM}$ followed by 45 minutes of aerobic training at $60-90 \%$ of their maximal heart rate. Nevertheless, this training programme resulted in other positive effects such as gains in lean mass, reduced fat mass and improved aerobic capacity. ${ }^{[160]}$

Bone mass improvement has been observed in older men (mean age 61 years) after a relatively short training period. ${ }^{[161]}$ In this study, femoral neck BMD was enhanced by $2.8 \%$ following 3 months of high-intensity training (5 RM; three times per week). ${ }^{[161]}$ These results could be conflicting, because Frost ${ }^{[172]}$ has argued that short-term increases in BMD measured by photon absorptiometry may reflect transient increases.

In general, 1-3\% BMD improvement in loaded bones can be achieved in old men with 6 months of strength training using heavy loads (above $70 \%$ of $1 \mathrm{RM}$, three times per week), while loads below $60 \%$ of $1 \mathrm{RM}$ are unlikely to have a positive influence on bone mass. ${ }^{[173]}$

\section{Practical Recommendations}

Any prescription of exercise aiming to improve bone mass must take into consideration the following factors:

(i) Age and sex of the subjects. At prepubertal and young adult ages, sex differences are not so important, but at middle and older age, evidence from the literature suggests that women have to train at higher intensities than men to improve their bone mass, always keeping a security range to avoid injuries.

(ii) Choice and order of the exercises. Since bone adaptation is limited to loaded regions, exercise must be chosen to specifically act on the clinically relevant sites, i.e. lumbar and thoracic spine, whole hip, and especially greater trochanter, intertrochanteric and femoral neck regions. The easiest and safest way to load these regions is by using weight-lifting exercises like: leg press, leg extension, leg curl, squats, loaded back extensions, and some shoulder and arm exercises. If not contraindicated, the training programme should include impact exercises like jumping, jogging, stair climbing and sprinting. Impact exercises must be increased progressively to the maximal effort possible according to the subject's specific capabilities. The kind of impact exercise included in the programme must be appropriate for the age of the participants, trying to keep the risk of fall as low as possible in the elderly. It must be taken into consideration that the osteogenic potential of jumping exercise is reduced in postmenopausal women, but postmenopausal women may respond well to strength training.

(iii) Intensity. To enhance bone mass the threshold intensity must be reached. This level has not been unequivocally established and may vary from subject to subject, probably being lower for subjects with already reduced bone mass. Most strength training programmes showing positive effects on bone mass have used intensities of 70-90\% 1 RM, always following an appropriate progression from lower to higher intensities.

(iv) Frequency. Most studies with positive results have used 2-3 training days per week. However, good responses to jumping exercise sessions with 
frequencies up to 6 days per week have also been reported. Weight-bearing endurance exercise (30-60 minutes) can be carried out three to five times, or even on a daily basis, depending on training experience and tolerance.

(v) Volume. In weight-lifting programmes, the major muscle groups of the upper and lower extremities must be trained in a balanced way, without creating imbalance between agonist and antagonist. The number of repetitions per exercise must be close to maximal that can be performed with a given load and 2-3 sets should be completed, with 1-3 minutes' resting periods in between. With regard to high impact training, there is no consensus in the literature on how many jumps must be performed, but depending on the subject's tolerance, 50-100 jumps should be carried out each training day. Strength training combined with high impact exercise could have additive effects in some subjects.

(vi) Movement velocity. Although a progression from medium to high speed of movement is advocated at the start of the training programme, as soon as subjects are able to carry out the exercise safely, i.e. with proper biomechanical execution, movements must be performed focusing on achieving the maximal execution speed possible. Explosive muscle contractions are expected to elicit a greater osteogenic stimulus. ${ }^{[155]}$

\section{Conclusions}

The research completed to date indicates that participation in high impact sports, especially prior to puberty, is important for maximizing bone mass accumulation and achieving a greater peak bone mass independent of sex. The effects of loading appear to be limited to the loaded bones. Starting the exercise before puberty has an additional benefit, since exercise elicits geometrical changes in bone, which in turn enhance mechanical competence. Continuing sport practice is associated with fewer bone fragility fractures in old age in both men and women.

Several training methods have been used to improve BMD and content in prospective studies. Not all exercise modalities have positive effects on bone mass. For example, unloaded exercise, like swimming and cycling, has no impact on bone mass, while walking or running has limited positive effects.

It is not clear which is the best training method for enhancing bone mass, although scientific evidence points to a combination of high impact exercises (i.e. jumping) with weight-lifting exercises. High impact exercise, even a limited amount, appears to be the most efficient to enhance bone mass except in postmenopausal women. Several types of resistance exercise have been tested with positive results when the intensity of the exercise was high and the speed of movement elevated. Resistance training is positively associated with high BMD in both young people and adults, and the effect of resistive exercise is relatively site specific to the working muscles and the bones to which they attach. However, more studies are needed to establish whether there are sex differences in the bone response to training. Although aerobic exercise and weight-bearing physical activity are important in maintaining overall health and healthy bones, resistance exercise has been shown to have a more potent effect on bone density. Studies performed in older adults show a sex discrepancy. Older men respond better to osteogenic training protocols than their female counterparts, although randomized longitudinal studies on the effects of exercise on bone mass in the elderly are still lacking. Old women show only mild increases or just a maintenance or attenuation of BMD losses. It remains to be determined if old women need a different exercise protocol to men of similar age.

Impact and resistance exercise should be advocated for the prevention of osteoporosis. For those with osteoporosis, weight-bearing exercise in general, and resistance exercise in particular, as tolerated, along with exercise targeted to improve balance, mobility and posture, should be recommended to reduce the likelihood of falling and its associated morbidity and mortality.

There is certainly a need for additional randomized, controlled trials in this research area, which will allow development of criteria for appropriate training loads according to age, sex, actual bone mass and past training history. 


\section{Acknowledgements}

The study was supported financially by Ministerio de Educación y Ciencia (DEP2006-56076-C06-04/ACTI). Consejería de Educación, Cultura y Deportes del Gobierno de Canarias (2006/179 0001 and FEDER). Borja Guerra is a fellow of the 'Recursos Humanos y Difusión de la Investigación' Program (ISCIII, MSC, Spain). The authors thank José Navarro de Tuero for his excellent technical assistance. The specialized advice from Tony Webster in editing the English version of the manuscript is also acknowledged. The authors have no conflicts of interest that are directly relevant to the content of this review.

\section{References}

1. Bouxsein ML, Karasik D. Bone geometry and skeletal fragility. Curr Osteoporos Rep 2006; 4 (2): 49-56

2. Viguet-Carrin S, Garnero P, Delmas PD. The role of collagen in bone strength. Osteoporos Int 2006; 17 (3): 319-36

3. Seeman E, Delmas PD. Bone quality: the material and structural basis of bone strength and fragility. $\mathrm{N}$ Engl $\mathbf{J}$ Med 2006; 354 (21): 2250-61

4. Ottani V, Raspanti M, Ruggeri A. Collagen structure and functional implications. Micron 2001; 32 (3): 251-60

5. Currey JD. Changes in the impact energy absorption of bone with age. J Biomech 1979; 12 (6): 459-69

6. Currey JD. The effect of porosity and mineral content on the Young's modulus of elasticity of compact bone. J Biomech 1988; 21 (2): 131-9

7. Currey JD, Brear K, Zioupos P. The effects of ageing and changes in mineral content in degrading the toughness of human femora. J Biomech 1996; 29 (2): 257-60

8. Bailey AJ, Wotton SF, Sims TJ, et al. Post-translational modifications in the collagen of human osteoporotic femoral head. Biochem Biophys Res Commun 1992; 185 (3): 801-5

9. Boskey AL, Wright TM, Blank RD. Collagen and bone strength. J Bone Miner Res 1999; 14 (3): 330-5

10. Wang X, Bank RA, TeKoppele JM, et al. The role of collagen in determining bone mechanical properties. J Orthop Res 2001; 19 (6): 1021-6

11. Currey JD. The mechanical consequences of variation in the mineral content of bone. J Biomech 1969; 2 (1): 1-11

12. Niyibizi C, Eyre DR. Structural characteristics of crosslinking sites in type $\mathrm{V}$ collagen of bone: chain specificities and heterotypic links to type I collagen. Eur J Biochem 1994; 224 (3): 943-50

13. Eyre DR, Dickson IR, Van Ness K. Collagen cross-linking in human bone and articular cartilage: age-related changes in the content of mature hydroxypyridinium residues. Biochem J 1988; 252 (2): 495-500

14. Fantner GE, Birkedal H, Kindt JH, et al. Influence of the degradation of the organic matrix on the microscopic fracture behavior of trabecular bone. Bone 2004; 35 (5): 1013-22

15. Banse X, Sims TJ, Bailey AJ. Mechanical properties of adult vertebral cancellous bone: correlation with collagen intermolecular cross-links. J Bone Miner Res 2002; 17 (9): 1621-8

16. Fantner GE, Hassenkam T, Kindt JH, et al. Sacrificial bonds and hidden length dissipate energy as mineralized fibrils separate during bone fracture. Nat Mater 2005; 4 (8): 612-6

17. Hert J, Fiala P, Petrtyl M. Osteon orientation of the diaphysis of the long bones in man. Bone 1994; 15 (3): 269-77

18. Martin RB, Boardman DL. The effects of collagen fiber orientation, porosity, density, and mineralization on bovine cortical bone bending properties. J Biomech 1993; 26 (9): 1047-54

19. Puustjarvi K, Nieminen J, Rasanen $T$, et al. Do more highly organized collagen fibrils increase bone mechanical strength in loss of mineral density after one-year running training? J Bone Miner Res 1999; 14 (3): 321-9

20. Harada S, Rodan GA. Control of osteoblast function and regulation of bone mass. Nature 2003; 423 (6937): 349-55

21. Pavy-Le Traon A, Heer M, Narici MV, et al. From space to earth: advances in human physiology from 20 years of bed rest studies (1986-2006). Eur J Appl Physiol 2007; 101 (2): 143-94

22. Chilibeck PD, Sale DG, Webber CE. Exercise and bone mineral density. Sports Med 1995; 19 (2): 103-22

23. Frost HM. Bone's mechanostat: a 2003 update. Anat Rec A Discov Mol Cell Evol Biol 2003; 275 (2): 1081-101

24. Rittweger $\mathbf{J}$. What is new in neuro-musculoskeletal interactions: mechanotransduction, microdamage and repair? J Musculoskel Neuron Interact 2007; 7 (2): 191-3

25. Rosen CJ. Bone remodeling, energy metabolism, and the molecular clock. Cell Metab 2008; 7 (1): 7-10

26. Lee KC, Lanyon LE. Mechanical loading influences bone mass through estrogen receptor alpha. Exerc Sport Sci Rev 2004; 32 (2): 64-8

27. Skerry TM. One mechanostat or many? Modifications of the site-specific response of bone to mechanical loading by nature and nurture. J Musculoskel Neuron Interact 2006; 6 (2): $122-7$

28. Scott A, Khan KM, Duronio V, et al. Mechanotransduction in human bone: in vitro cellular physiology that underpins bone changes with exercise. Sports Med 2008; 38 (2): $139-60$

29. Rubin J, Rubin C, Jacobs CR. Molecular pathways mediating mechanical signaling in bone. Gene 2006; 367: 1-16

30. Saxon LK, Lanyon LE. Assessment of the in vivo adaptive response to mechanical loading. Method Molec Biol 2008; 455: 307-22

31. Frost HM. Bone "mass" and the "mechanostat": a proposal. Anat Rec 1987; 219 (1): 1-9

32. Frost HM. Wolff's law: an 'MGS' derivation of gamma in the Three-Way Rule for mechanically controlled lamellar bone modeling drifts. Bone Miner 1993; 22 (2): 117-27

33. Bailey CA, Brooke-Wavell K. Exercise for optimising peak bone mass in women. Proc Nutr Soc 2008; 67 (1): 9-18

34. Shaw J. Exercise for skeletal health and osteoporosis prevention: ACSM's resource manual for guidelines for exercise testing and prescription. Philadelphia (PA): Lippincott Williams \& Wilkins, 1998: 288-93 
35. Frost HM. Skeletal structural adaptations to mechanical usage (SATMU): 1, redefining Wolff's law - the bone modeling problem. Anat Rec 1990; 226 (4): 403-13

36. Burr DB, Forwood MR, Fyhrie DP, et al. Bone microdamage and skeletal fragility in osteoporotic and stress fractures. J Bone Miner Res 1997; 12 (1): 6-15

37. Rubin CT, Lanyon LE. Regulation of bone formation by applied dynamic loads. J Bone Joint Surg Am 1984; 66 (3): 397-402

38. Rubin C, Turner AS, Bain S, et al. Anabolism: low mechanical signals strengthen long bones. Nature 2001; 412 (6847): 603-4

39. Rubin C, Turner AS, Muller R, et al. Quantity and quality of trabecular bone in the femur are enhanced by a strongly anabolic, noninvasive mechanical intervention. J Bone Miner Res 2002; 17 (2): 349-57

40. Borer KT. Physical activity in the prevention and amelioration of osteoporosis in women: interaction of mechanical, hormonal and dietary factors. Sports Med 2005; 35 (9): 779-830

41. Nordström A, Karlsson C, Nyquist F, et al. Bone loss and fracture risk after reduced physical activity. J Bone Miner Res 2005; 20 (2): 202-7

42. WHO Study Group. Assessment of fracture risk and its application to screening for postmenopausal osteoporosis. World Health Organ Tech Rep Ser 1994; 843: $1-129$

43. Cummings SR, Nevitt MC, Browner WS, et al. Risk factors for hip fracture in white women: Study of Osteoporotic Fractures Research Group. N Engl J Med 1995; 332 (12): $767-73$

44. Kanis JA, Melton 3rd LJ, Christiansen C, et al. The diagnosis of osteoporosis. J Bone Miner Res 1994; 9 (8): $1137-41$

45. Mein AL, Briffa NK, Dhaliwal SS, et al. Lifestyle influences on 9-year changes in BMD in young women. J Bone Miner Res 2004; 19 (7): 1092-8

46. Vicente-Rodriguez G. How does exercise affect bone development during growth? Sports Med 2006; 36 (7): 561-9

47. Vicente-Rodriguez G, Jimenez-Ramirez J, Ara I, et al. Enhanced bone mass and physical fitness in prepubescent footballers. Bone 2003; 33 (5): 853-9

48. Vicente-Rodriguez G, Dorado C, Perez-Gomez J, et al. Enhanced bone mass and physical fitness in young female handball players. Bone 2004; 35 (5): 1208-15

49. Vicente-Rodriguez G, Dorado C, Ara I, et al. Artistic versus rhythmic gymnastics: effects on bone and muscle mass in young girls. Int J Sports Med 2007; 28 (5): 386-93

50. McVeigh JA, Norris SA, Pettifor JM. Bone mass accretion rates in pre- and early-pubertal South African black and white children in relation to habitual physical activity and dietary calcium intakes. Acta Paediatr 2007; 96 (6): 874-80

51. Vicente-Rodriguez G, Ara I, Perez-Gomez J, et al. High femoral bone mineral density accretion in prepubertal soccer players. Med Sci Sports Exerc 2004; 36 (10): $1789-95$

52. Wang Q, Alen M, Nicholson P, et al. Weight-bearing, muscle loading and bone mineral accrual in pubertal girls: a 2-year longitudinal study. Bone 2007; 40 (5): 1196-202
53. Bradney M, Pearce G, Naughton G, et al. Moderate exercise during growth in prepubertal boys: changes in bone mass, size, volumetric density, and bone strength: a controlled prospective study. J Bone Miner Res 1998; 13 (12): 1814-21

54. Bass SL. The prepubertal years: a uniquely opportune stage of growth when the skeleton is most responsive to exercise? Sports Med 2000; 30 (2): 73-8

55. Bailey DA, McKay HA, Mirwald RL, et al. A six-year longitudinal study of the relationship of physical activity to bone mineral accrual in growing children: the university of Saskatchewan bone mineral accrual study. J Bone Miner Res 1999; 14 (10): 1672-9

56. Greene DA, Naughton GA. Adaptive skeletal responses to mechanical loading during adolescence. Sports Med 2006; 36 (9): 723-32

57. Bass SL, Saxon L, Daly RM, et al. The effect of mechanical loading on the size and shape of bone in pre-, peri-, and postpubertal girls: a study in tennis players. J Bone Miner Res 2002; 17 (12): 2274-80

58. Seeman E. An exercise in geometry. J Bone Miner Res 2002; 17 (3): 373-80

59. Kannus P, Haapasalo H, Sankelo M, et al. Effect of starting age of physical activity on bone mass in the dominant arm of tennis and squash players. Ann Intern Med 1995; 123 (1): $27-31$

60. Heinonen A, Sievanen H, Kannus P, et al. High-impact exercise and bones of growing girls: a 9-month controlled trial. Osteoporos Int 2000; 11 (12): 1010-7

61. Manias K, McCabe D, Bishop N. Fractures and recurrent fractures in children; varying effects of environmental factors as well as bone size and mass. Bone 2006; 39 (3): $652-7$

62. Laing EM, Wilson AR, Modlesky CM, et al. Initial years of recreational artistic gymnastics training improves lumbar spine bone mineral accrual in 4- to 8-year-old females. J Bone Miner Res 2005; 20 (3): 509-19

63. Lanyon LE. Using functional loading to influence bone mass and architecture: objectives, mechanisms, and relationship with estrogen of the mechanically adaptive process in bone. Bone 1996; 18 (1 Suppl.): 37S-43S

64. Martyn-St James M, Carroll S. Progressive high-intensity resistance training and bone mineral density changes among premenopausal women: evidence of discordant site-specific skeletal effects. Sports Med 2006; 36 (8): 683-704

65. Forwood MR, Turner CH. The response of rat tibiae to incremental bouts of mechanical loading: a quantum concept for bone formation. Bone 1994; 15 (6): 603-9

66. Pazzaglia UE, Andrini L, Di Nucci A. The effects of mechanical forces on bones and joints: experimental study on the rat tail. J Bone Joint Surg Br 1997; 79 (6): 1024-30

67. Robling AG, Duijvelaar KM, Geevers JV, et al. Modulation of appositional and longitudinal bone growth in the rat ulna by applied static and dynamic force. Bone 2001; 29 (2): 105-13

68. Ehrlich PJ, Lanyon LE. Mechanical strain and bone cell function: a review. Osteoporos Int 2002; 13 (9): 688-700 
69. Pedersen BK, Hoffman-Goetz L. Exercise and the immune system: regulation, integration, and adaptation. Physiol Rev 2000; 80 (3): 1055-81

70. Van Hall G, Jensen-Urstad M, Rosdahl H, et al. Leg and arm lactate and substrate kinetics during exercise. Am J Physiol Endocrinol Metab 2003; 284 (1): E193-205

71. Mastorakos G, Pavlatou M. Exercise as a stress model and the interplay between the hypothalamus-pituitary-adrenal and the hypothalamus-pituitary-thyroid axes. Horm Metab Res 2005; 37 (9): 577-84

72. Calbet JA, Lundby C, Sander M, et al. Effects of ATPinduced leg vasodilation on $\mathrm{VO} 2$ peak and leg $\mathrm{O} 2$ extraction during maximal exercise in humans. Am J Physiol Regul Integr Comp Physiol 2006; 291 (2): R447-53

73. Ara I, Perez-Gomez J, Vicente-Rodriguez G, et al. Serum free testosterone, leptin and soluble leptin receptor changes in a 6-week strength-training programme. Br J Nutr 2006; 96 (6): 1053-9

74. Frost HM, Jee WS. On the rat model of human osteopenias and osteoporoses. Bone Miner 1992; 18 (3): 227-36

75. Bourrin S, Palle S, Pupier R, et al. Effect of physical training on bone adaptation in three zones of the rat tibia. J Bone Miner Res 1995; 10 (11): 1745-52

76. Yeh JK, Liu CC, Aloia JF. Effects of exercise and immobilization on bone formation and resorption in young rats. Am J Physiol 1993; 264 (2 Pt 1): E182-9

77. Hagihara Y, Fukuda S, Goto S, et al. How many days per week should rats undergo running exercise to increase BMD? J Bone Miner Metab 2005; 23 (4): 289-94

78. Barengolts EI, Curry DJ, Bapna MS, et al. Effects of endurance exercise on bone mass and mechanical properties in intact and ovariectomized rats. J Bone Miner Res 1993; 8 (8): 937-42

79. Horcajada M, Coxam V, Davicco M, et al. Influence of treadmill running on femoral bone in young orchidectomized rats. J Appl Physiol 1997; 83 (1): 129-33

80. van der Wiel HE, Lips P, Graafmans WC, et al. Additional weight-bearing during exercise is more important than duration of exercise for anabolic stimulus of bone: a study of running exercise in female rats. Bone 1995; 16 (1): 73-80

81. Bourrin S, Genty C, Palle S, et al. Adverse effects of strenuous exercise: a densitometric and histomorphometric study in the rat. J Appl Physiol 1994; 76 (5): 1999-2005

82. Iwamoto J, Takeda T, Sato Y. Effect of treadmill exercise on bone mass in female rats. Exp Anim 2005; 54 (1): 1-6

83. Wronski TJ, Yen CF. The ovariectomized rat as an animalmodel for postmenopausal bone loss. Cell Mater Suppl 1991; 1: 69-74

84. Jarvinen TL, Kannus P, Pajamaki I, et al. Estrogen deposits extra mineral into bones of female rats in puberty, but simultaneously seems to suppress the responsiveness of female skeleton to mechanical loading. Bone 2003; 32 (6): 642-51

85. Sanchis-Moysi J, Dorado C, Vicente-Rodriguez G, et al. Inter-arm asymmetry in bone mineral content and bone area in postmenopausal recreational tennis players. Maturitas 2004; 48 (3): 289-98
86. Calbet JA, Dorado C, Diaz-Herrera P, et al. High femoral bone mineral content and density in male football (soccer) players. Med Sci Sports Exerc 2001; 33 (10): 1682-7

87. Morel J, Combe B, Francisco J, et al. Bone mineral density of 704 amateur sportsmen involved in different physical activities. Osteoporos Int 2001; 12 (2): 152-7

88. Calbet JA, Moysi JS, Dorado C, et al. Bone mineral content and density in professional tennis players. Calcif Tissue Int 1998; 62 (6): 491-6

89. Wittich A, Mautalen CA, Oliveri MB, et al. Professional football (soccer) players have a markedly greater skeletal mineral content, density and size than age- and BMImatched controls. Calcif Tissue Int 1998; 63 (2): 112-7

90. Egan E, Reilly T, Giacomoni M, et al. Bone mineral density among female sports participants. Bone 2006; 38 (2): 227-33

91. Nichols JF, Rauh MJ, Barrack MT, et al. Bone mineral density in female high school athletes: interactions of menstrual function and type of mechanical loading. Bone 2007; 41 (3): 371-7

92. Alfredson H, Nordström P, Lorentzon R. Total and regional bone mass in female soccer players. Calcif Tissue Int 1996; 59 (6): 438-42

93. Ducher G, Prouteau S, Courteix D, et al. Cortical and trabecular bone at the forearm show different adaptation patterns in response to tennis playing. J Clin Densitom 2004; 7 (4): 399-405

94. Karlsson MK. Skeletal effects of exercise in men. Calcif Tissue Int 2001; 69 (4): 196-9

95. Layne JE, Nelson ME. The effects of progressive resistance training on bone density: a review. Med Sci Sports Exerc 1999; 31 (1): $25-30$

96. Nichols DL, Sanborn CF, Essery EV. Bone density and young athletic women: an update. Sports Med 2007; 37 (11): 1001-14

97. Karlsson M. Has exercise an antifracture efficacy in women? Scand J Med Sci Sports 2004; 14 (1): 2-15

98. Daly RM, Rich PA, Klein R, et al. Effects of high-impact exercise on ultrasonic and biochemical indices of skeletal status: a prospective study in young male gymnasts. J Bone Miner Res 1999; 14 (7): 1222-30

99. Taaffe DR, Snow-Harter C, Connolly DA, et al. Differential effects of swimming versus weight-bearing activity on bone mineral status of eumenorrheic athletes. J Bone Miner Res 1995; 10 (4): 586-93

100. Hawkey A. The importance of exercising in space. Interdiscip Sci Rev 2003; 28 (2): 130-8

101. Perez-Gomez J, Olmedillas H, Delgado-Guerra S, et al. Effects of weight lifting training combined with plyometric exercises on physical fitness, body composition, and knee extension velocity during kicking in football. Appl Physiol Nutr Metab 2008; 33 (3): 501-10

102. Kellis E, Katis A, Vrabas IS. Effects of an intermittent exercise fatigue protocol on biomechanics of soccer kick performance. Scand J Med Sci Sports 2006; 16 (5): 334-44

103. Hetland ML, Haarbo J, Christiansen C. Low bone mass and high bone turnover in male long distance runners. J Clin Endocrinol Metab 1993; 77 (3): 770-5 
104. Kannus P, Haapasalo H, Sievanen H, et al. The site-specific effects of long-term unilateral activity on bone mineral density and content. Bone 1994; 15 (3): 279-84

105. Haapasalo H, Kannus P, Sievanen H, et al. Long-term unilateral loading and bone mineral density and content in female squash players. Calcif Tissue Int 1994; 54 (4): 249-55

106. Ducher G, Tournaire N, Meddahi-Pelle A, et al. Shortterm and long-term site-specific effects of tennis playing on trabecular and cortical bone at the distal radius. J Bone Miner Metab 2006; 24 (6): 484-90

107. Vicente-Rodriguez G. How does exercise affect bone development during growth? Sports Med 2006; 36 (7): 561-9

108. Calbet JA, Dorado C, Diaz-Herrera P, et al. High femoral bone mineral content and density in male football (soccer) players. Med Sci Sports Exerc 2001; 33 (10): 1682-7

109. Egan E, Reilly T, Giacomoni M, et al. Bone mineral density among female sports participants. Bone 2006; 38 (2): 227-33

110. Ng MY, Sham PC, Paterson AD, et al. Effect of environmental factors and gender on the heritability of bone mineral density and bone size. Ann Hum Genet 2006; 70 (Pt 4): 428-38

111. Kemper HC, Post GB, Twisk JW, et al. Lifestyle and obesity in adolescence and young adulthood: results from the Amsterdam Growth And Health Longitudinal Study (AGAHLS). Int J Obes Relat Metab Disord 1999; 23 Suppl. 3: S34-40

112. Armstrong N, Welsman JR. The physical activity patterns of European youth with reference to methods of assessment. Sports Med 2006; 36 (12): 1067-86

113. Tanner JM. Principles of growth standards. Acta Paediatr Scand 1990; 79 (10): 963-7

114. Friedlander AL, Genant HK, Sadowsky S, et al. A twoyear program of aerobics and weight training enhances bone mineral density of young women. J Bone Miner Res 1995; 10 (4): 574-85

115. Schroeder ET, Hawkins SA, Jaque SV. Musculoskeletal adaptations to 16 weeks of eccentric progressive resistance training in young women. J Strength Cond Res 2004; 18 (2): $227-35$

116. Hawkins SA, Schroeder ET, Wiswell RA, et al. Eccentric muscle action increases site-specific osteogenic response. Med Sci Sports Exerc 1999; 31 (9): 1287-92

117. Nickols-Richardson SM, Miller LE, Wootten DF, et al. Concentric and eccentric isokinetic resistance training similarly increases muscular strength, fat-free soft tissue mass, and specific bone mineral measurements in young women. Osteoporos Int 2007; 18 (6): 789-96

118. Kato T, Terashima T, Yamashita T, et al. Effect of lowrepetition jump training on bone mineral density in young women. J Appl Physiol 2006; 100 (3): 839-43

119. Bassey EJ, Ramsdale SJ. Increase in femoral bone density in young women following high-impact exercise. Osteoporos Int 1994; 4 (2): 72-5

120. Sinaki M, Wahner HW, Bergstralh EJ, et al. Three-year controlled, randomized trial of the effect of dose-specified loading and strengthening exercises on bone mineral density of spine and femur in nonathletic, physically active women. Bone 1996; 19 (3): 233-44
121. Chilibeck PD, Calder A, Sale DG, et al. Twenty weeks of weight training increases lean tissue mass but not bone mineral mass or density in healthy, active young women. Can J Physiol Pharmacol 1996; 74 (10): 1180-5

122. Nindl BC, Harman EA, Marx JO, et al. Regional body composition changes in women after 6 months of periodized physical training. J Appl Physiol 2000; 88 (6): 2251-9

123. Lohman T, Going S, Pamenter R, et al. Effects of resistance training on regional and total bone mineral density in premenopausal women: a randomized prospective study. J Bone Miner Res 1995; 10 (7): 1015-24

124. Vainionpää A, Korpelainen R, Leppaluoto J, et al. Effects of high-impact exercise on bone mineral density: a randomized controlled trial in premenopausal women. Osteoporos Int 2005; 16 (2): 191-7

125. Winters-Stone KM, Snow CM. Site-specific response of bone to exercise in premenopausal women. Bone 2006; 39 (6): 1203-9

126. Heinonen A, Kannus P, Sievanen H, et al. Randomised controlled trial of effect of high-impact exercise on selected risk factors for osteoporotic fractures. Lancet 1996; 348 (9038): 1343-7

127. Kohrt WM, Bloomfield SA, Little KD, et al. American College of Sports Medicine Position Stand: physical activity and bone health. Med Sci Sports Exerc 2004; 36 (11): 1985-96

128. Deschenes MR, Kraemer WJ. Performance and physiologic adaptations to resistance training. Am J Phys Med Rehabil 2002; 81 (11 Suppl.): S3-16

129. Kraemer WJ, Ratamess NA. Fundamentals of resistance training: progression and exercise prescription. Med Sci Sports Exerc 2004; 36 (4): 674-88

130. Kraemer WJ, Mazzetti SA, Nindl BC, et al. Effect of resistance training on women's strength/power and occupational performances. Med Sci Sports Exerc 2001; 33 (6): 1011-25

131. Kraemer WJ, Nindl BC, Ratamess NA, et al. Changes in muscle hypertrophy in women with periodized resistance training. Med Sci Sports Exerc 2004; 36 (4): 697-708

132. Uusi-Rasi K, Sievanen H, Pasanen M, et al. Association of physical activity and calcium intake with the maintenance of bone mass in premenopausal women. Osteoporos Int 2002; 13 (3): 211-7

133. Snow-Harter C, Bouxsein ML, Lewis BT, et al. Effects of resistance and endurance exercise on bone mineral status of young women: a randomized exercise intervention trial. J Bone Miner Res 1992; 7 (7): 761-9

134. Mayhew TP, Rothstein JM, Finucane SD, et al. Muscular adaptation to concentric and eccentric exercise at equal power levels. Med Sci Sports Exerc 1995; 27 (6): 868-73

135. Gilsanz V, Wren TA, Sanchez M, et al. Low-level, highfrequency mechanical signals enhance musculoskeletal development of young women with low BMD. J Bone Miner Res 2006; 21 (9): 1464-74

136. Fujimura R, Ashizawa N, Watanabe M, et al. Effect of resistance exercise training on bone formation and resorption in young male subjects assessed by biomarkers of bone metabolism. J Bone Miner Res 1997; 12 (4): 656-62

137. Hartman JW, Tang JE, Wilkinson SB, et al. Consumption of fat-free fluid milk after resistance exercise promotes 
greater lean mass accretion than does consumption of soy or carbohydrate in young, novice, male weightlifters. Am J Clin Nutr 2007; 86 (2): 373-81

138. Ballard TL, Specker BL, Binkley TL, et al. Effect of protein supplementation during a 6-month strength and conditioning program on areal and volumetric bone parameters. Bone 2006; 38 (6): 898-904

139. Ryan AS, Ivey FM, Hurlbut DE, et al. Regional bone mineral density after resistive training in young and older men and women. Scand J Med Sci Sports 2004; 14 (1): $16-23$

140. Mullins NM, Sinning WE. Effects of resistance training and protein supplementation on bone turnover in young adult women. Nutr Metab (Lond) 2005; 2: 19

141. Torvinen S, Kannus P, Sievanen H, et al. Effect of 8-month vertical whole body vibration on bone, muscle performance, and body balance: a randomized controlled study. J Bone Miner Res 2003; 18 (5): 876-84

142. Beck BR, Kent K, Holloway L, et al. Novel, highfrequency, low-strain mechanical loading for premenopausal women with low bone mass: early findings. J Bone Mineral Metab 2006; 24 (6): 505-7

143. Menkes A, Mazel S, Redmond RA, et al. Strength training increases regional bone mineral density and bone remodeling in middle-aged and older men. J Appl Physiol 1993; 74 (5): 2478-84

144. Huuskonen J, Vaisanen SB, Kroger H, et al. Regular physical exercise and bone mineral density: a four-year controlled randomized trial in middle-aged men - the DNASCO study. Osteoporos Int 2001; 12 (5): 349-55

145. Stewart KJ, Bacher AC, Hees PS, et al. Exercise effects on bone mineral density relationships to changes in fitness and fatness. Am J Prev Med 2005; 28 (5): 453-60

146. Madeo B, Zirilli L, Caffagni G, et al. The osteoporotic male: overlooked and undermanaged? Clin Interv Aging 2007; 2 (3): 305-12

147. Hui SL, Slemenda CW, Johnston Jr CC, et al. The contribution of bone loss to postmenopausal osteoporosis. Osteoporos Int 1990; 1 (1): 30-4

148. Jones HH, Priest JD, Hayes WC, et al. Humeral hypertrophy in response to exercise. J Bone Joint Surg Am 1977; 59 (2): 204-8

149. Province MA, Hadley EC, Hornbrook MC, et al. The effects of exercise on falls in elderly patients: a preplanned meta-analysis of the FICSIT Trials. Frailty and injuries: cooperative studies of intervention techniques. JAMA 1995; 273 (17): 1341-7

150. Paganini-Hill A, Chao A, Ross RK, et al. Exercise and other factors in the prevention of hip fracture: the Leisure World study. Epidemiology 1991; 2 (1): 16-25

151. Wyshak G, Frisch RE, Albright TE, et al. Bone fractures among former college athletes compared with nonathletes in the menopausal and postmenopausal years. Obstet Gynecol 1987; 69 (1): 121-6

152. Nelson ME, Fiatarone MA, Morganti CM, et al. Effects of high-intensity strength training on multiple risk factors for osteoporotic fractures: a randomized controlled trial. JAMA 1994; 272 (24): 1909-14
153. Kerr D, Morton A, Dick I, et al. Exercise effects on bone mass in postmenopausal women are site-specific and loaddependent. J Bone Miner Res 1996; 11 (2): 218-25

154. Kohrt WM, Snead DB, Slatopolsky E, et al. Additive effects of weight-bearing exercise and estrogen on bone mineral density in older women. J Bone Miner Res 1995; 10 (9): 1303-11

155. Stengel SV, Kemmler W, Pintag R, et al. Power training is more effective than strength training for maintaining bone mineral density in postmenopausal women. J Appl Physiol 2005; 99 (1): 181-8

156. Chien MY, Wu YT, Hsu AT, et al. Efficacy of a 24-week aerobic exercise program for osteopenic postmenopausal women. Calcif Tissue Int 2000; 67 (6): 443-8

157. Kohrt WM, Ehsani AA, Birge Jr SJ, et al. Effects of exercise involving predominantly either joint-reaction or ground-reaction forces on bone mineral density in older women. J Bone Miner Res 1997; 12 (8): 1253-61

158. Verschueren SM, Roelants M, Delecluse C, et al. Effect of 6-month whole body vibration training on hip density, muscle strength, and postural control in postmenopausal women: a randomized controlled pilot study. J Bone Miner Res 2004; 19 (3): 352-9

159. Pruitt LA, Jackson RD, Bartels RL, et al. Weight-training effects on bone mineral density in early postmenopausal women. J Bone Miner Res 1992; 7 (2): 179-85

160. Maddalozzo GF, Snow CM. High intensity resistance training: effects on bone in older men and women. Calcif Tissue Int 2000; 66 (6): 399-404

161. Ryan AS, Treuth MS, Rubin MA, et al. Effects of strength training on bone mineral density: hormonal and bone turnover relationships. J Appl Physiol 1994; 77 (4): 1678-84

162. Ryan AS, Treuth MS, Hunter GR, et al. Resistive training maintains bone mineral density in postmenopausal women. Calcif Tissue Int 1998; 62 (4): 295-9

163. Bassey EJ, Rothwell MC, Littlewood JJ, et al. Pre- and postmenopausal women have different bone mineral density responses to the same high-impact exercise. J Bone Miner Res 1998; 13 (12): 1805-13

164. Sugiyama T, Yamaguchi A, Kawai S. Effects of skeletal loading on bone mass and compensation mechanism in bone: a new insight into the "mechanostat" theory. J Bone Miner Metab 2002; 20 (4): 196-200

165. Palombaro KM. Effects of walking-only interventions on bone mineral density at various skeletal sites: a metaanalysis. J Geriatr Phys Ther 2005; 28 (3): 102-7

166. Bergmann G, Graichen F, Rohlmann A. Hip joint loading during walking and running, measured in two patients. J Biomech 1993; 26 (8): 969-90

167. Gusi N, Raimundo A, Leal A. Low-frequency vibratory exercise reduces the risk of bone fracture more than walking: a randomized controlled trial. BMC Musculoskel Disord 2006; 7: 92

168. Rubin C, Recker R, Cullen D, et al. Prevention of postmenopausal bone loss by a low-magnitude, highfrequency mechanical stimuli: a clinical trial assessing compliance, efficacy, and safety. J Bone Miner Res 2004; 19 (3): $343-51$ 
169. Zehnacker $\mathrm{CH}$, Bemis-Dougherty A. Effect of weighted exercises on bone mineral density in post menopausal women: a systematic review. J Geriatr Phys Ther 2007; 30 (2): 79-88

170. Englund U, Littbrand H, Sondell A, et al. The beneficial effects of exercise on BMD are lost after cessation: a 5 -year follow-up in older post-menopausal women. Scand J Med Sci Sports. Epub 2008 May 22

171. Mackey DC, Lui LY, Cawthon PM, et al. High-trauma fractures and low bone mineral density in older women and men. JAMA 2007; 298 (20): 2381-8
172. Frost HM. Some effects of basic multicellular unit-based remodelling on photon absorptiometry of trabecular bone. Bone Miner 1989; 7 (1): 47-65

173. Forwood MR, Burr DB. Physical activity and bone mass: exercises in futility? Bone Miner 1993; 21 (2): 89-112

Correspondence: Prof. Jose A.L. Calbet, Departamento de Educación Física, Campus Universitario de Tafira, 35017 Las Palmas de Gran Canaria, Canary Islands, Spain. E-mail: lopezcalbet@gmail.com 